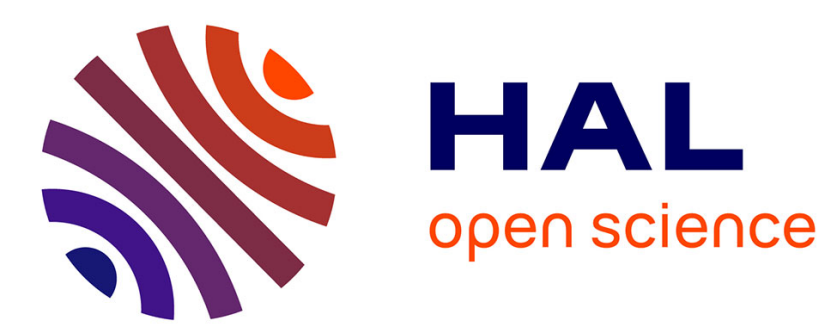

\title{
Investigation on the Comparative Persistence and Convergence of Risk and Non-Risk Adjusted Bank Capital Ratios
}

Clovis Rugemintwari

\section{- To cite this version:}

Clovis Rugemintwari. Investigation on the Comparative Persistence and Convergence of Risk and Non-Risk Adjusted Bank Capital Ratios. 2010. hal-00916749

\section{HAL Id: hal-00916749 \\ https: / hal-unilim.archives-ouvertes.fr/hal-00916749}

Preprint submitted on 10 Dec 2013

HAL is a multi-disciplinary open access archive for the deposit and dissemination of scientific research documents, whether they are published or not. The documents may come from teaching and research institutions in France or abroad, or from public or private research centers.
L'archive ouverte pluridisciplinaire HAL, est destinée au dépôt et à la diffusion de documents scientifiques de niveau recherche, publiés ou non, émanant des établissements d'enseignement et de recherche français ou étrangers, des laboratoires publics ou privés. 


\title{
Investigation on the comparative persistence and convergence of risk and non-risk adjusted bank capital ratios.
}

\author{
Clovis RUGEMINTWARI ${ }^{1}$ \\ University of Limoges, LAPE, 5 rue Félix Eboué BP3127, 87031 Limoges, France
}

First version: June 2010

This version: September 2010

\begin{abstract}
We depart from the fact that in Europe, unlike the leverage ratio, risk-based capital ratios are formally under capital regulation with specified minimum thresholds to be respected. Building on this difference, we study their comparative persistence and convergence. For this purpose, we borrow the graphical analysis of Lemmon et al. (2008) and use the empirical partial adjustment model. Overall, consistent with the findings from the corporate finance literature, we find that bank capital structure is quite stable over long periods of time: banks that have high (low) capital ratios tend to remain as such for over eight years. Nevertheless, we find that even though all future capital ratios are influenced by initial capital ratios, this influence seems comparatively more relevant for the non risk-based (or leverage) capital ratio highlighting its high persistent phenomenon. Our findings also point to the role played by market participants in the trend and the relative rapid convergence of the risk-adjusted capital ratios compare to the simple leverage ratio. Our results are thus broadly supportive of recent policy initiatives that aim to strengthen the bank capital regulation by introducing a minimum leverage ratio and by simultaneously improving market discipline.
\end{abstract}

Key words: Prudential regulation, Basel accords, Bank capital structure, Leverage ratio, Market discipline.

JEL Classification Numbers: G21, G28, G32.

\footnotetext{
${ }^{1}$ Tel: +33 (0)5 551492 05. E-Mail : clovis.rugemintwari@,unilim.fr

The earlier version of this paper has been previously presented at the $27^{\text {th }}$ GDRe Symposium on Money Banking and Finance in Bordeaux under the title "Persistence and cross-section of capital structure: are banks different from non financial firms?" I thank all the seminar participants, particularly Jérôme Coffinet for his insights. I have also benefited from helpful discussions with my supervisor Prof. Alain Sauviat, Philippe Rous and Isabelle Distinguin. All errors are my own.
} 


\section{Introduction}

In a recent paper, Lemmon, Roberts and Zender (2008) (LRZ for short thereafter) study the persistence and the cross-section of capital structure in corporate firms. They mainly show that corporate leverage ratios exhibit a significant amount of convergence over time; firms with relatively high (low) leverage tend to move toward more moderate levels of leverage. However, they also show that despite this convergence, leverage ratios are remarkably stable over time; firms with relatively high (low) leverage tend to maintain relatively high (low) leverage for over twenty years. Therefore, leverage ratios are characterized by both a transitory and a permanent component. They also found that the majority of variation in corporate capital structure is time-invariant and that much of this variation is unaccounted for by existing empirical specifications. Hence, the main implication of their results is the fact that the static pooled OLS regressions are inadequate and they pleaded for a model that takes into account those individual fixed effects. The first aim of our paper is thus to investigate the extent to which these observations from non financial firms apply to banks. Even though to our knowledge this paper is the first to analyse this issue in the banking case, the approach of taking insights from corporate literature or comparing financial with non financial firms is not new. We can trace back this approach to Miller (1995) when he investigated if the Modigliani-Miller propositions apply to banks. Morgan (2002), Flannery et al. (2004) and Haggard and Howe (2007) meanwhile study the relative opacity of banks compare to non financial firms.

The closest paper to ours is Gropp and Heider (2010) (GH thereafter) who study to what extent corporate capital structure determinants explain bank capital structure using the large publicly traded banks in US and Europe ${ }^{2}$. They established important similarities between banks' and nonfinancial firms' capital structure and hence conclude on the second order importance that capital regulation plays in determining the bank capital structure. This comparative approach adopted in GH's paper in order to investigate the role played by the capital regulation (Basel accords) in the bank capital structure is informative and yet suffers from a key drawback in our view. Although they refer to the tierl capital ratio in the sixth section (table XII), they mainly focus on the banking leverage whereas in Europe there is no formal capital regulation applied to this ratio (as opposed to the US case where the PCA sets

\footnotetext{
${ }^{2}$ An earlier paper by Barber and Lyon (1997) is close in spirit to GH's paper by investigating if the significant relationship between firm size, book-to-market ratios, and security returns documented by Fama and French (1992) for non financial firms exists for financial firms.
} 
formal limits to the leverage). Therefore, the second aim of our paper seeks to fill this gap by systematically comparing the bank leverage with risk-adjusted capital ratios to uncover their differences and hence infer the role of capital regulation if $a^{3} y^{3}$. This investigation is interesting because, beyond re-instating the role played by the minimum regulatory capital, our results could help us to conjecture the potential trend of the leverage ratio once it is introduced in the bank capital regulation.

The rest of the paper is organized as follows: section II details the data and the graphical analysis. Section III outlines the econometric approach adopted to conduct our empirical analysis. Section IV presents the results. Section V details the different robustness checks that we undertake and section VI concludes the paper.

\section{Data and Graphical analysis}

Contrary to LRZ who considered a time period of 39 years (from 1965 to 2003), we use a rather shorter time period of 15 years (from 1992 to 2006). We recall that our main aim is to empirically compare regulated and unregulated (leverage) capital ratios in Europe. Therefore, we consider the period corresponding to the Basel I accords which forced banks to satisfy a regulatory minimum capital ratio of $8 \%$. The year 2006 is chosen as the end of our time period to avoid any impact of regulatory modifications on our results ${ }^{4}$.

Bankscope Fitch IBCA reported balance sheets and income statements for 1985 commercial banks for the 16 European countries considered in this paper. Among these 1985 commercial banks the information on the total capital ratio ${ }^{5}$ was missing for 1219 banks. Moreover, looking at the distribution of this ratio, 24 other banks were considered as outliers. Hence, we ended up with the final sample of 742 commercial banks over the period 19922006. All our data come from Bankscope except for the real GDP series which were retrieved from Datastream. Appendix A presents the distribution of banks by country. Appendix B details several tests conducted to probe the stationarity of our data.

\footnotetext{
${ }^{3}$ Two other main differences between GH and our paper can be highlighted: the first is the particular emphasis we attach to the role played by bank specific variables on both the leverage and the risk-adjusted capital ratios (see Section III for details). Secondly, we develop a graphical analysis which is very important as it gives us first hand evidence on bank capital structure and portrays its transitory and permanent nature.

${ }^{4}$ Since 2007 banks shifted to Basel II and currently there are discussions to include the leverage ratio (among other things) in the capital regulation menu (Basel III).

${ }^{5}$ The total capital ratio is one of our three dependent variables (see Section III for details).
} 
In this section we develop the method borrowed from LRZ. We investigate graphically how the initial capital ratios influence the future capital ratios by looking at the evolution of bank leverage, tier1 and total risk-based capital ratios for our cross section of banks. This graphical approach is well-suited to visualize the comparative persistence and convergence of the different bank capital ratios considered in this study. It allows us to basically understand how both the regulated and the non regulated capital ratios evolve through time and the impact of initial capital ratio on the future capital ratio.

\section{-Figure 1 about here-}

To this end, Figure 1 presents the average of a given capital ratio of four bank groupings in "event time." It is constructed in the following manner. First, for each calendar year, we sort banks into quartiles that give us four bank groupings according to the level of the considered capital ratio (leverage, tier 1 or total capital ratios alternatively), which we denote: Very High, High, Medium, and Low. Second, we compute the average capital ratio for each grouping at its formation year and in each of the subsequent seven years, holding its composition constant. To illustrate, consider for example 1992 which is our first grouping formation year. We sort banks and form the grouping representing banks in the first quartile and compute the average ratio (only for this group of banks) from 1992 to 1999. We repeat these two steps of sorting and averaging for every year in the sample period (15 years from 1992 to 2006) ${ }^{6}$. This process generates 15 sets of averages, one for each calendar year in our sample. After, we compute the average of the averages ratio within each event time to obtain the points in the figure ${ }^{7}$. We perform this exercise for all the three ratios (leverage, tier1 and total risk-based capital ratios), the results of which are presented in Figure 1 for the category "all banks".

The main concern in interpreting Figure 1 is the fact that some banks exit the sample either because of bankruptcy or mergers and acquisitions operations as we progress away from the grouping formation year (see Table 1). This is particularly troublesome if we consider that banks that exit the sample are mainly those with very low capital ratios (through

\footnotetext{
${ }^{6}$ Notice that from 1999 onward, we lose a year in the length of the time we can follow the bank grouping. For instance, in 2000, it can only be followed during six years whereas in 2006, the last year of our sample, it is impossible to follow the bank grouping. Table 1 detailed below gives an idea about this structure.

${ }^{7}$ On the whole, we have eight event times and the number of averages used to compute the final points within each event time decreases as we progress further (from 15 for event time 1 to 8 for event time 8).
} 
bankruptcy) or very high capital ratios (through M\&A operations ${ }^{8}$ ) and therefore the exit may mechanically impact the way the capital ratios evolve in the figure.

\section{-Insert Table 1 about here-}

Each line of Table 1 shows how the number of banks evolves from the bank grouping formation year and the consecutive seven years during which we follow this grouping. For instance in 1992, 39 banks have a leverage ratio belonging to the first quartile called "Low" and seven years after, in 1999, more than $38 \%$ of the banks have exited the sample. We construct similar tables (not presented here due to space considerations) for the three remaining categories (Medium, High, Very High) and for the two other capital ratios (Tier 1 and Total capital ratios). To control for this exiting problem, we therefore repeat the whole process of construction of the Figure 1 by constraining the grouping to contain the same number of banks from the year of formation up to the end of the period during which we maintain the bank grouping constant ${ }^{9}$. The number of banks used to compute the averages is given in italics in the Table 1 and the results are depicted in Figure 1 for survivor banks where we notice that the evolution of the capital ratios does not change.

The charts in Figure 1 highlight several features that are worth noting. First, we notice an important cross-sectional dispersion at event time 1. For all three ratios, the gap between the Very High and the Low groups is substantial: 11.08, 12.29 and $14.28 \%$ for the leverage, tier 1 and total risk-based capital ratios respectively. Second, there is a substantial convergence among the four bank groupings averages over time, particularly for the riskbased capital ratios. For instance, the chart in the middle (for the sample of all banks) shows that after 8 years, the Very High Tier 1 capital ratio grouping declined from $18.24 \%$ to $12.96 \%$, whereas the Low grouping increased from 5.95\% to $7.65 \%$. The total capital ratio groupings display a similar pattern, but the first chart which represents the leverage ratio seems to show a slower speed of convergence. Understanding this difference in convergence speed is one of the aims of this paper. Finally, despite the convergence, the average capital ratio across the bank groupings eight years later remains significantly different for all capital ratios. Banks with low capital ratios level at the beginning (event time 1) disclose a low

\footnotetext{
${ }^{8}$ Valkanov and Kleimeier (2007) show that bank targets are better capitalized than bank acquirers.

${ }^{9}$ Our robustness check is more restrictive compared to that of LRZ who only require firms to have nonmissing data on book leverage at least on 20 out of 39 years.
} 
capital ratio level eight years later (event time 8). Overall, we obtain consistent results with those of LRZ, particularly on the bank leverage ratio.

The main implication from Figure 1 is that banks' future leverage and risk-based capital ratios are closely related to their initial leverage and risk-based capital ratios consistent with the persistence of bank capital structure. However, despite this persistent phenomenon, we notice that bank capital ratios tend to converge towards their targets at different pace. The risk-adjusted capital ratios disclose high speed of convergence compared to the leverage ratio. However, the charts provide limited quantitative evidence of the initial ratios' economic importance. To measure the impact of initial bank capital ratios on future bank capital ratios and thoroughly investigate the question of convergence, we therefore proceed econometrically.

\section{Econometric procedure}

In this section we discuss how we empirically test the first hand evidence shown in Figure 1. We firstly examine the question of the persistence of the bank capital structure and then we go through the investigation related to the different speeds of convergence between the leverage and the risk-adjusted capital ratios.

For the first question, our procedure is close to that of LRZ who test whether the initial leverage explains much of the future firms' leverage. We estimate an econometric model of the following form:

$$
\operatorname{Cap}_{i, t}=\alpha+\beta \operatorname{Cap}_{i, o}+\sum_{c=1}^{5} \gamma_{c} T_{i, t}+\sum_{d=1}^{6} \delta_{d} B S_{i, t}+v_{t}+\varepsilon_{i, t}
$$

$\operatorname{Cap}_{i, o}, T$, and $B S$ stand for initial capital, traditional and bank specific variables as detailed in Appendix C. The parameter $\beta$ associated with the first component is the one of great importance. Subscripts $i$ and $t$ denote bank and period respectively. We include in the regression time fixed effects ${ }^{10} v_{t}$ to account for unobserved heterogeneity across time that may be correlated with the explanatory variables.

\footnotetext{
${ }^{10}$ We do not consider country fixed effects as GH because our sample is less heterogeneous by excluding the American banks. We also hope to capture them through the variables in the second component (T): economic cycle and the competition computed at the country level. However, for comparison reasons, several robustness checks regarding fixed effects and model specification were undertaken (see Section V for details).
} 
In this model, the dependent variable Cap represents the bank capital structure. We consider three alternative dependent variables: in addition to the leverage ratio, defined as Total equity divided by Total assets, traditionally used in the corporate literature; we also consider the tier 1 and the total capital ratios ${ }^{11}$ respectively defined as Tier 1 capital/ Risk weighted assets and Total capital/ Risk weighted assets. These two variables allow us to take into account the specificity of banks that appears in the bank capital regulation reflected in the minimum regulatory capital requirement imposed by the Basel accords. Our aim is to compare how the determinants of bank capital structure, particularly the first (initial capital) and the third (bank specific variables) components influence the unregulated and regulated capital ratios. In this way, we are able not only to compare our results to those by LRZ for non financial firms, but also extend the study by GH by tracking how within banking firms regulated and unregulated capital ratios respond to the impact exercised by the different determinants described below. Concerning the independent variables, beyond the initial capital borrowed from LRZ, the paper draws heavily on previous works that have looked into how banks choose their capital structure. We identify several factors and classify them into traditional and bank specific variables. Now, we describe the three different sets of independent variables.

The first set is made of initial capital ( Cap $\left._{i, o}\right)$. It means the initial leverage or the initial tier 1 or total capital ratios which are the first nonmissing values of these ratios. They should have a significant positive impact on future bank capital ratios in accordance with the persistence phenomenon found in Figure 1. In order to isolate the part of bank capital structure explained by this first component we control for two other components. The first component, which is the second set of independent variables, controls for shared factors generally found to influence both financial and non financial capital structure. We call them traditional variables (T). They are size, equity cost which should be negatively linked to bank capital ratios and profit, economic cycle, and competition which are supposed to have a positive impact on bank capital ratios ${ }^{12}$. The second component, and hence the last set of independent variables, consists of the bank specific features (as opposed to non financial firms) embedded in the bank balance sheet. We try to capture the effect of the credit risk and the asset structure from the asset side and the impact of market discipline by looking at the type of bank creditors from the liability side in order to assess their impact on capital ratios.

\footnotetext{
${ }^{11}$ Definitions of all variables in italics can also be found in Appendix $\mathrm{C}$ along with their descriptive statistics and the expected signs of their coefficients.

${ }^{12}$ The explanations for the expected impact of the traditional variables on the bank capital ratios are intuitive and could be found in Alfon et al. (2004) and Berger et al. (2008) for instance.
} 
For this purpose, we consider the ratio of Loan loss provision over Total assets as the credit risk variable and a prudent behavior should be associated with a positive relationship between this variable and the bank capital ratios. We also consider the variables credit demandmeasured as the annual net loan growth rate, and credit activity- corresponding to the proportion of net loans in total assets that should be negatively related to the bank capital ratios. Indeed, an increase in assets through the demand of credit should decrease the capital ratio as the denominator increases all else being equal (Ayuso et al. (2004)). We also know that the Basel I accords were mainly designed to deal with bank credit activities. Despite the 1996 modifications to include market risks, it is generally agreed that they remain ill-suited for market activities (BIS (2009)) and hence we may expect that banks highly involved in the credit activities could operate with low capital ratios by comparison.

To assess the market discipline effect, we construct two quantitative indicators (Nier and Baumann (2006)) and a price indicator (Demirgüç-Kunt and Huizinga (2004)). Therefore, we consider the proportion of all market fundings in total liabilities and the proportion of bank deposits $^{13}$ in total liabilities. From the market discipline point of view, we expect a positive relationship between these two variables and the dependent variables reflecting the pressure emanating from uninsured debt holders. We add a third market discipline variable as a price indicator termed Liability cost equal to the ratio of interest expense to interest-bearing debt. We assume that if the debt is not completely insured, market discipline makes banks substitute capital to debt when their cost increases. Thus, we expect a positive link between Liability cost and our dependent variables.

One major difficulty for our analysis is that some of the independent variables are likely to be endogenous, i.e. themselves dependent on bank capital. While the initial capital variable $\left(\mathrm{Cap}_{i, o}\right)$ is strictly exogenous, endogeneity is likely to be a problem for some of the traditional and the bank specific variables. In particular, banks that hold little capital may have to rely on attracting bank deposits or other uninsured funding in order to fund their assets. This would result in a negative relationship between capital and the bank deposit ratio and between capital and the ratio of uninsured liabilities. On the other hand, banks that hold little equity capital could be perceived as risky by investors. This could increase their cost of uninsured funding and reduce their reliance on such funds, resulting in a positive relationship between capital and bank deposits and between capital and uninsured liabilities. Potential

\footnotetext{
${ }^{13}$ Bank deposits are deposits received from other banks and they are not explicitly insured.
} 
endogeneity biases therefore need to be addressed by a suitable choice of estimation method. The two closest papers to ours (Lemmon et al. (2008) and Gropp and Heider (2010) have dealt with this issue by using lagged variables in the Panel pooled OLS. We rather opt for a more appropriate GMM technique and the pooled OLS is used as a robustness check ${ }^{14}$. All our variables were instrumented except those representing the initial capital, or at the country level (economic cycle) or those variables for the credit demand (which is a growth rate) and the bank size as they are obviously exogenous. As regards to the set of instruments, we follow the literature and consider lagged values of the concerned endogenous variable consistent with the satisfaction of the Sargan J-statistic for over-identification restrictions.

Concerning our second point, we take a step further to closely examine the question of convergence. Our aim is to empirically assess the findings shown in Figure 1 where riskadjusted bank capital ratios seem to converge towards bank capital targets faster than the simple leverage ratio. In this perspective, we transform equation (1) into a partial adjustment model as it is traditionally the case both in the corporate literature (Flannery and Rangan (2006)) and the banking literature (Flannery and Rangan (2008), Berger et al. (2008), Brewer et al. (2008)). The partial adjustment model is derived from:

$\Delta \operatorname{Cap}_{i, t}=\Delta^{d} \operatorname{Cap}_{i, t}+\omega_{i, t}(2)$ where the observed change in a banking institution's capital ratio at any time is decomposed into a discretionary adjustment to its targeted equilibrium ratio and an adjustment caused by exogenous current events. Given that the bank may not be able to adjust its target equilibrium capital ratio instantaneously, expression(2) can be modified and modelled in a partial adjustment framework. It becomes:

$\Delta \operatorname{Cap}_{i, t}=\lambda\left(\operatorname{Cap}_{i, t}^{*}-\operatorname{Cap}_{i, t-1}\right)+\omega_{i, t}$ (3) where $\operatorname{Cap}_{i, t}^{*}$ is the desired capital ratio and it is assumed to be given by expression(1).$\lambda \in[0,1]$ stands for the speed of adjustment (SOA) ${ }^{15}$ in which we are interested. The rest of the paper discusses the results and different robustness checks performed to probe their strength.

\section{Results}

\footnotetext{
${ }^{14}$ See footnote 10 .

${ }^{15}$ Notice that $(3)$ can be re-written as: $\operatorname{Cap}_{i, t}=(1-\lambda) \operatorname{Cap}_{i, t-1}+\lambda \operatorname{Cap}_{i, t}^{*}+\varepsilon_{i, t}$ and hence, the SOA can be easily derived by taking 1 minus the coefficient associated with the dependent lagged variable.
} 
Tables 2 and 3 give our main results obtained respectively with models (1) and (3) . We start by describing the results contained in Table 2 .

\section{-Insert Table 2 about here-}

In each column (1) of Table 2, we present the results of a model specification consisting solely of the initial capital variable, that is initial leverage or initial risk-based capital ratios, which is one of our main focus because it enables us to compare our results to those by LRZ for non financial firms. The coefficient is statistically and economically highly significant for all three dependent variables in columns (I), (II), and (III) indicating that the future bank capital ratio highly depends on its initial capital ratio. We can see that a one unit change in initial leverage, tier1 and total capital ratios result respectively in $73 \%, 57 \%$ and $53 \%$ change in future bank leverage, tier1 and total capital ratios. This result is consistent with the permanent feature of leverage ratio found by LRZ for corporate firms. Moreover it is consistent with our Figure 1 which discloses a more persistent phenomenon for the leverage than for the risk-adjusted capital ratios as the coefficient is on average a quarter higher for the former. Hence, this quantitative result confirms the graphical one found in figure 1 which shows that despite convergence, banks with low or high capital ratios remain as such on average seven years after. Next, we add two sets of variables in the model ${ }^{16}$. The first set (column (2)) corresponds to the traditional variables which may influence bank capital ratios. The coefficient estimates are all consistent with previous literature, in terms of sign and significance for the three dependent variables, except for the competition variable which is not significant for the tier1 ratio dependent variable (II). The final set consists of bank specific variables added in two separate waves in order to ease the comparison between the impact they have on the leverage with that on the risk-adjusted capital ratios. Our aim here is to compare the impact of the bank specific determinants on formally regulated capital ratios (risk-adjusted capital ratios) and unregulated leverage ratio ${ }^{17}$. Column (3) contains the results with the addition of variables reflecting the bank specificities at the asset side. Coefficients have the expected negative sign significant at the $1 \%$ for the three dependent variables except for the credit risk variable which is not significant. The notable difference is in the

\footnotetext{
${ }^{16}$ Although the magnitude of the coefficient of the initial capital variable decreases once we add other explanatory variables, it remains economically significant across all the specifications.

${ }^{17}$ In this way, we can test the relevance of capital regulation on bank capital structure and complement the recent results by Gropp and Heider (2010).
} 
coefficients' magnitude where those associated with the risk-adjusted capital ratios are 3 to 7 times higher than those associated with the leverage ratio. Column (4) gives the results where we incorporate the last sub-set of bank capital structure determinants related to market discipline reflected in the bank liability side. As expected from the market discipline perspective, the three added variables Market fundings, Bank deposits and Liability cost have positive and significant coefficients at the $1 \%$ for the total risk-based capital ratio. By contrast, none of the three variables comes out as expected for the leverage ratio. The only significant variable Bank deposits has a negative coefficient which does not play the role of market discipline. Instead, this result is consistent with the substitution effect theorized by Gorton and Winton (2000). When the bank increases its financing with the bank deposits, then it will lower its recourse on capital. Hence, even though the same Bank deposits variable is not significant for the tier 1 capital ratio, the results in column (4) establish a stark difference between the risk-adjusted dependent variable and the leverage ratio. Hence, it clearly appears that, at least in Europe, uninsured creditors seem to discipline only the riskbased capital ratios, which is formally regulated. Another notable feature to highlight is the stability of our coefficients in terms of magnitude, signs and significance across all the model specifications.

To better grasp the effect of each added set of variables from model specification (1) to (4) used to explain the future leverage and the risk-based capital ratios, we compare the Rsquares (together with their variations) disclosed in the last two rows of Table 2. First, we find that the initial capital variable captures, in absolute terms, much of the future capital ratio consistent with the findings by LRZ who find similar results concerning corporate capital leverage. In relative terms however, we notice that the initial capital variable is more important for the leverage regression (64.54\% in column (I.1)) than for the risk-based capital ratios regression (53\% and $44.35 \%$ column (1) in regressions II and III respectively). This is consistent with the charts from Figure 1 which shows a higher persistent pattern for the leverage ratio than for risk-based capital ratios. In other words, while the regulated capital ratios are influenced by the initial capital, this influence is more pronounced for the unregulated (or the leverage) capital ratio. Hence, our suspicion that the bank capital regulation might play a prominent part in the explanation of the risk-adjusted capital ratio. Second, the traditional variables contribute to the explanation of the future leverage ratio more than to the explanation of the future risk-based capital ratios as the increase in the Rsquare is more than $14 \%$ in the first case whereas it is less than $6 \%$ on average in the second 
case. The opposite occurs when we consider the contribution of the bank specific variables as they do not add that much to the explanation of the future leverage capital ratio (less than $0.5 \%$ increase $^{18}$ ) whereas they contribute more than $12 \%$ on average for the explanation of the future risk-based capital ratios. Now, we discuss the results contained in Table 3 obtained with the partial adjustment model(3).

\section{-Insert Table 3 about here-}

We follow LRZ and progressively add different sets of determinants of the target bank capital in order to compare factors responsible for the speed of adjustment (SOA) variation. We maintain the same procedure as previously (Table 2) except the addition of the first column which gives the SOA when the target specification is solely made of the intercept term. The coefficient in the first row (SOA) is our main focus for understating the different speeds of convergence between the leverage and the risk-adjusted capital ratios highlighted on Figure 1. Consistent with the graphical analysis, we can see that the SOA is 2 times higher at least in every column of Table 3 for the risk-adjusted capital ratios than for the leverage. Every column (2) of the three dependent variables shows that the initial capital variable remains highly significant despite the presence of the one year lagged dependent variable and that the SOA increases (in relative terms ${ }^{19}$ ) of $52.88 \%, 19.21 \%$ and $29.84 \%$ respectively for the leverage, Tier 1 and the Total capital ratios. This empirical result corroborates the persistent phenomenon found in Figure 1. Moreover, consistent with the first empirical evidence in Table 2, the addition of the bank specific variables (Columns (4) and (5)) has very stark different impact on the SOA of the leverage and the risk-adjusted capital ratios. Whereas the risk-adjusted capital SOA increases of more than 5\%, that of the leverage ratio does not increase (it rather decreases!). We can also notice that 2 out of 3 market discipline indicators are significant with positive coefficients whereas none of them is significant for the leverage ratio.

Overall, we get very sensible results consistent with the current practice in the banking regulation in Europe that only focuses on the risk-based capital ratios. This is shown by the relative great importance of initial leverage on future leverage on the one hand, and the

\footnotetext{
${ }^{18}$ Although this increase is small, the added variables jointly contribute significantly to the explanatory power of the model as indicated by the Wald test.

${ }^{19}$ The relative variation is computed as: $(S O A(2)-S O A(1)) / S O A(1)$.
} 
irrelevance of market discipline on future leverage on the other hand. In other words, our results may suggest that the fact that risk-based capital ratios are formally under capital regulation with specified minimum thresholds to be respected makes market participants care about their evolution. We conjecture that the potential introduction of the leverage capital ratio into the bank capital regulation menu could dampen the weight of initial leverage ratio that it has on its future trend and it could be more sensitive to market discipline ${ }^{20}$.

\section{Robustness tests}

In this section we report a number of robustness checks that were undertaken to verify the overall strength of our results. In particular, we introduce a number of changes to the benchmark specifications shown in Tables 2 and 3 and check whether the results change significantly. To save space, we only report results with two dependent variables as results with the Tier 1 are quite similar to those with the total risk-based capital ratio. First, one can suspect that the magnitude of our R-squares are probably largely due to the inclusion of time fixed effects. To isolate their contribution to the model explanation, we re-run the model without the time fixed effects and compare the R-squares. The results are presented in Table 4. Overall, we find our results and conclusions with regards to the variable signs and significance, and the R-squares magnitude and variation to be robust to the exclusion of time fixed effects. The highest decline in the R-square is less than $3 \%$ for model specification II (2).

\section{-Insert Table 4 about here-}

Second, one could also argue that our benchmark regression does not completely take into account all the bank's aspects that might differ across countries despite the inclusion of two variables specific to each country (economic cycle and competition variables). In order to make sure that this potential lack does not distort our findings, we add a set of country dummy variables. Table 5 shows the results of this test. Overall, we find our results and conclusions to be robust to the inclusion of the country fixed effects. The only notable effect is the loss of the significance for the competition variable in all specifications as the country fixed effects capture its contribution. The same is true for the economic cycle variable which is significant only for the total risk-based capital ratio.

\footnotetext{
${ }^{20}$ A study that compares American and European banks could be one way to test this conjecture.
} 


\section{-Insert Table 5 about here-}

Third, the two previous studies Lemmon et al.(2008) and Gropp and Heider (2010) that are close to our paper and to which we compare our results have used the Panel Pooled Least Square (OLS) method. Thus, we re-estimate our models using the Pooled OLS in which the instruments replace the independent variables in order to dampen the endogeneity issue. Table 6 contains the results. Note that this robustness check allows us to verify if our results are very sensitive to the estimation method. Once again, we find that the choice of the econometric method does not have a marked effect on the interpretation of our results and conclusions.

\section{-Insert Table 6 about here-}

We performed another set of robustness checks not reported here but available upon request concerning our model specifications and our sample. For instance, we alternatively used pooled OLS with bank fixed effects and the Dynamic GMM using the Arellano and Bond (1998) first difference estimator which is believed to be better suited for studying the question of the speed of adjustment ${ }^{21}$. As argued in $\mathrm{GH}$, we found higher SOA (more than 2 times) and higher R-squares (more than 20\% and 30\% respectively for the leverage and total risk-based capital ratios) but our conclusions remained mainly unchanged. As regards to our sample, countries are not equally represented. In particular, France and Italy are highly represented by comparison. Moreover, capital regulation is somewhat different in UK where the Financial Stability Authority (FSA) sets two different capital ratios for each bank ${ }^{22}$. Hence, we alternatively exclude France and Italy, and UK in our sample and re-run all our regressions. We find that all our conclusions were unaffected.

\footnotetext{
${ }^{21}$ Initial capital variable which is stable through time was excluded.

22 A 'trigger ratio', which is the minimum individual capital ratio; and a 'target ratio' set above the trigger. The 'target ratio' acts as a warning light and as a cushion of capital to help prevent an accidental breach of the individual capital requirement (Alfon et al. (2004)).
} 


\section{Conclusion}

This paper examines empirically whether on the one hand the recent results found in the corporate literature by Lemmon, Roberts and Zender (2008) which indicates that much of the future firm leverage is explained by the initial leverage applies to the bank capital structure. On the other hand, we complement the study by Gropp and Heider (2010) who investigated the role played by the capital regulation in the bank capital structure. To do so, we use a homogenous sample of European commercial banks from 16 different countries from 1992 to 2006, a period during which the banking capital regulation has not changed and systematically compare the behavior of the unregulated leverage ratio to that of the regulated risk-based capital ratios.

Overall, consistent with the findings from the corporate literature, we find that bank capital structure is quite stable over long periods of time: banks that have relatively high (low) capital ratios tend to remain as such for over eight years. Moreover, as we analyze separately the risk-based capital ratios (tier 1 and total capital ratios) and the non risk-based capital ratio (leverage capital ratio), we find graphically a significant difference in the speed of convergence between them: convergence is faster for risk-based capital ratios than for leverage capital ratio. More interestingly, the econometric approach confirms this result. It shows that the future bank leverage depends on its initial leverage more than do the future bank risk-based capital ratios which seem to be rather much more influenced by the market discipline and the speed of adjustment of the latter is 2 times at least higher than the former. Hence, we think that the lack of a formal inclusion of the leverage ratio in the bank capital regulation package in Europe may explain this behavior. We can conclude that by specifying a minimum regulatory capital requirement, the Basel accords foster the market discipline which acts as a watchdog of the rules and thus ultimately influence the behavior of the riskadjusted capital ratios. On the whole, our results are therefore broadly supportive of recent policy initiatives that aim to strengthen the bank capital regulation by introducing a regulatory minimum for the leverage ratio and by simultaneously improving market discipline. 


\section{References}

Alfon, I., Argimon, I., Bascunana-Ambros, P., 2004. What determines how much capital is held by UK banks and building societies? Occasional paper No 22. UK Financial Services Authority.

Ayuso, J., Perez, D., Saurina, J., 2004, "Are capital buffers pro-cyclical? Evidence from Spanish panel data," Journal of Financial Intermediation 13, 249-264.

Baltagi, B., 2008, "Econometric Analysis of Panel Data," John Wiley and Sons. Fourth edition.

Barber, B. and Lyon, J., 1997, "Firm size, book-to-market ratio, and security returns: A holdout sample of financial firms," Journal of Finance 52, 875-883.

Basel Committee on Banking Supervision, 2009, "Revisions to the Basel II market risk framework," Bank for International Settlements, July.

Berger, A., R. DeYoung, M. J. Flannery, D. Lee., Ö. Öztekin, 2008, “How Do Large Banking Organizations Manage Their Capital Ratios?", Journal of Financial Services Research 34:123-149.

Brewer, E., Kaufman, G., Wall, L., 2008, "Bank capital ratios across countries: Why do they vary?," Journal of Financial Services Research 34, 177-201.

Demirgüç-Kunt, A. and H. Huizinga, 2004, "Market discipline and deposit insurance," Journal of Monetary Economics 51, 375-399.

Fama, E. and French, K., 1992, "The cross section of expected stock returns, Journal of Finance 47, 427-466.

Flannery, M. and Rangan, K., 2006, "Partial adjustment toward target capital structures," Journal of Financial Economics 79, 469-506.

Flannery, M., K. Rangan, 2008, "What Caused the Bank Capital Build-up of the 1990s?," Review of Finance 12, 391-429.

Flannery, M.J., S.H. Kwan, M. Nimalendran, 2004, "Market Evidence on the Opaqueness of Banking Firms' Assets," Journal of Financial Economics 71, 419-460.

Hlouskova, J. and M. Wagner, 2006, "The performance of panel unit root and stationarity tests: results from a large scale simulation study," Econometric Reviews 25, 85-116.

Gorton, G. and A. Winton, 2000, "Liquidity provision, bank capital, and the macroeconomy," University of Minnesota working paper.

Gropp, R., and F. Heider, 2010, "The determinants of Capital Structure," Review of Finance (2010) doi: 10.1093/rof/rfp030 
Haggard K. Stephen and John S. Howe, 2007, “Are Banks Opaque?,” Financial Management Association Annual Meeting, October 2007.

Lemmon, M., Roberts, M. and Zender, J., 2008, "Back to the beginning: Persistence and the cross-section of corporate capital structure," Journal of Finance 63, 1575-1608.

Karlsson, S. and M. Löthgren , 2000, " On the power and interpretation of panel unit root tests," Economics Letters 66, 249-255.

Miller, M., 1995, "Do the M\&M Propositions Apply to Banks?," Journal of Banking and Finance, 19, pp. 483-489.

Morgan, D.P., 2002. "Rating Banks: Risk and Uncertainty in an Opaque Industry," American Economic Review 92, 874-888.

Nier, E., and U. Baumann, 2006, "Market discipline, disclosure and moral hazard in banking", Journal of Financial Intermediation, Vol. 15, pp. 332-361.

Valkanov, E. and S. Kleimeier, 2007, "The role of regulatory capital in international bank mergers and acquisitions," Research in International Business and Finance 21, 50-68. 


\section{Appendix A: Distribution of banks by country}

The sample consists of 742 European commercial banks from Bankscope database from 1992 to 2006 .

\begin{tabular}{|cc|}
\hline Country & Number of banks \\
\hline \hline Austria & $\mathbf{1 9}$ \\
Belgium & $\mathbf{1 8}$ \\
Denmark & $\mathbf{6 5}$ \\
Finland & $\mathbf{1 1}$ \\
France & $\mathbf{1 4 7}$ \\
Germany & $\mathbf{2 8}$ \\
Greece & $\mathbf{1 8}$ \\
Ireland & $\mathbf{1 4}$ \\
Italy & $\mathbf{1 9 8}$ \\
Netherlands & $\mathbf{5 0}$ \\
Norway & $\mathbf{2 1}$ \\
Portugal & $\mathbf{2 0}$ \\
Spain & $\mathbf{3 1}$ \\
Sweden & $\mathbf{3 1}$ \\
Switzerland & $\mathbf{2 0}$ \\
United Kingdom & $\mathbf{5 1}$ \\
\hline Total & $\mathbf{7 4 2}$ \\
\hline
\end{tabular}

\section{Appendix B: Stationarity of the data}

It is important to check whether our panel data is stationary or not. In this perspective we performed four alternative tests (Baltagi, 2008, p.275). Three unit root tests: Levin, Lin and Chu (LLC), Im, Pesaran and Shin (IPS), Fisher-ADF and one stationarity test: Hadri. Notwithstanding the fact that for small time series $\mathrm{T}$, panel unit root tests have low power and thus there is a potential risk of concluding that the whole panel is nonstationary even when there is a large proportion of stationary series in the panel (Karlsson and Löthgren (2000)), all our 13 variables passed the three tests successfully at the $1 \%$ except the credit activity variable for which the null hypothesis (the presence of the unit root) is only rejected at $10 \%$ and the size variable for which we cannot reject the null hypthesis for the IPS and the FisherADF tests. Concerning the stationarity test Hadri which all our variables fail to pass, the rationale may be found in Hlouskova and Wagner (2006) who compare the performance of unit root and stationarity tests. They conclude that the stationarity test of Hadri (2000) perform poorly by comparison. Indeed, they found that for small time series, $T \in\{10,15\}^{23}$, it tends to reject stationarity most of the times even for highly stationary series and hence, they infer that it is hard to conduct such test for short times series.

\footnotetext{
${ }^{23}$ Which is our case as $\mathrm{T}=15$.
} 


\section{Appendix C: Descriptive statistics and definitions of the variables}

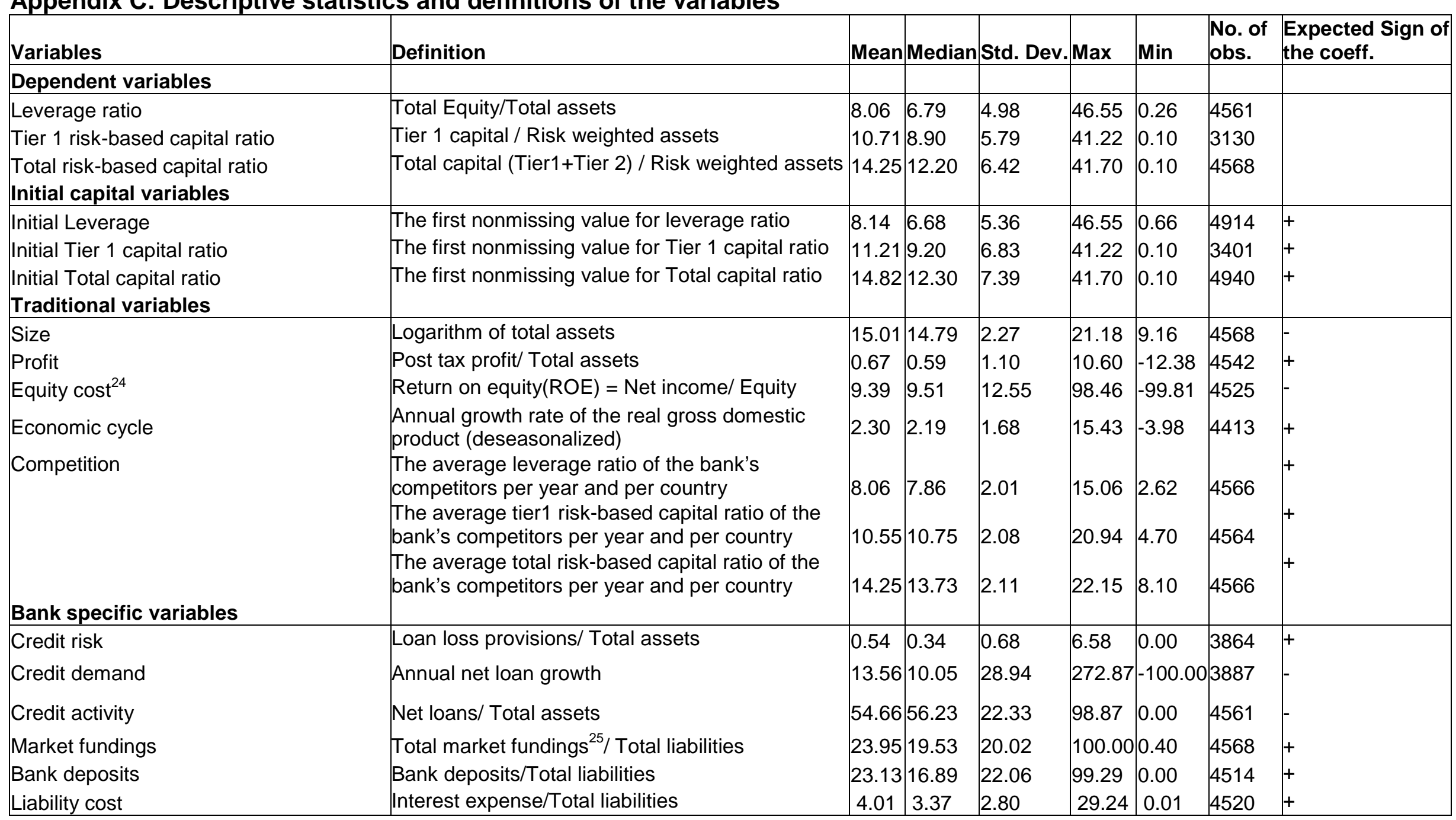

\footnotetext{
${ }^{24} \mathrm{ROE}$ and profit are highly correlated. Therefore, we proceed by orthogonalization and use the resids obtained by regressing ROE on profit as the equity cost variable.

${ }^{25}$ Total market fundings corresponds to Total Liabilities minus Total Deposits and Net loans are gross loans minus loan loss reserves.
} 
Figure 1: The Evolution of risk-based and non risk-based capital ratios.

All banks

Leverage capital ratio evolution

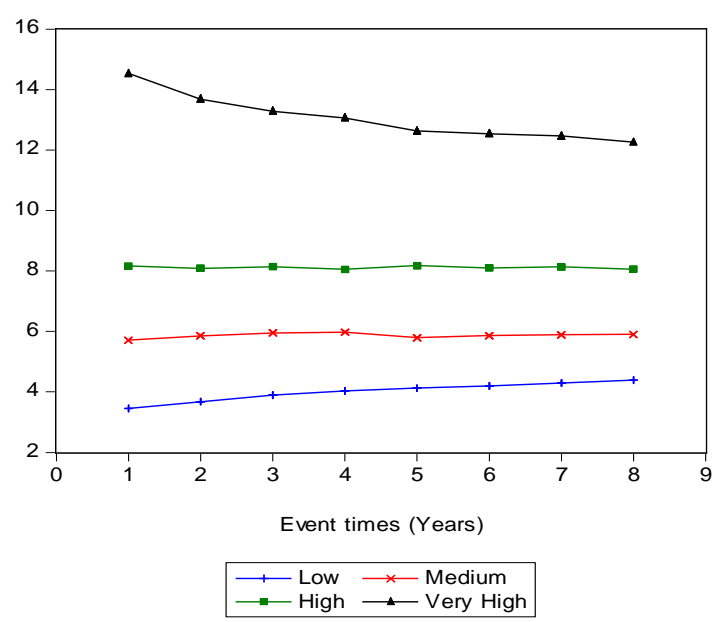

Tier 1 risk-based capital ratio evolution

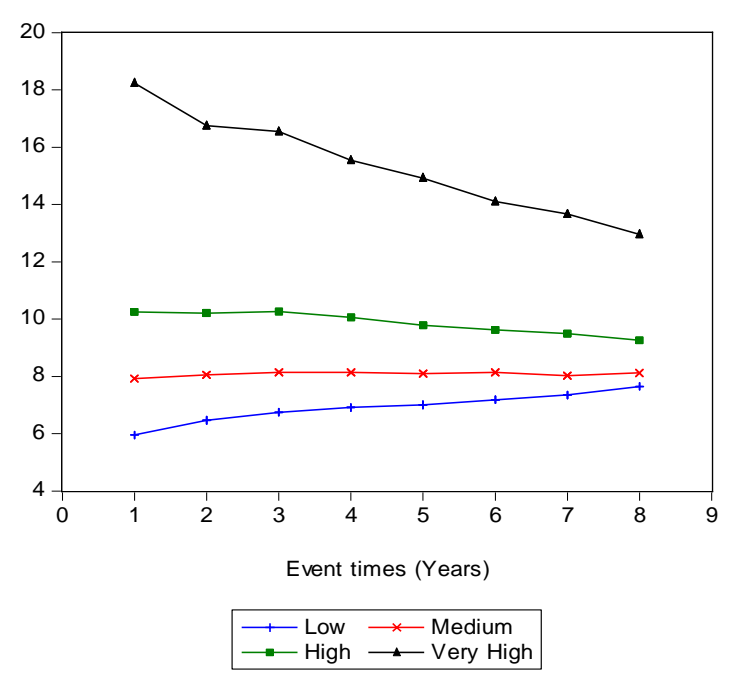

Total risk-based capital ratio evolution

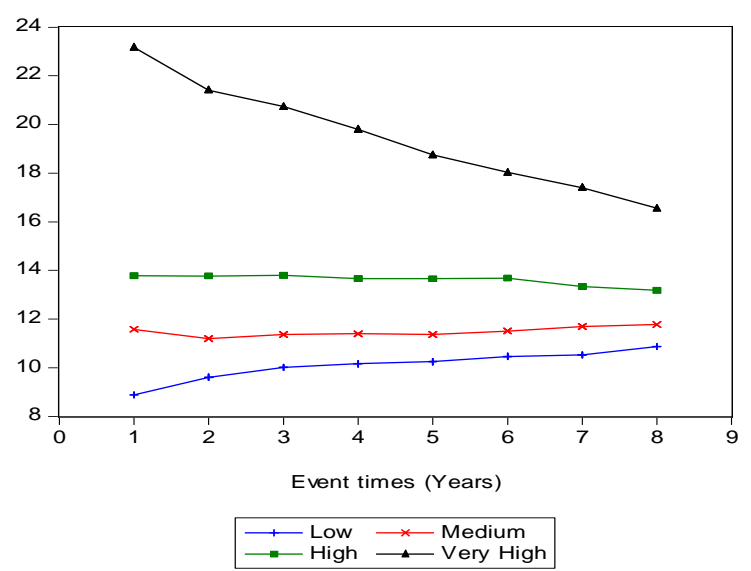

Survivor banks
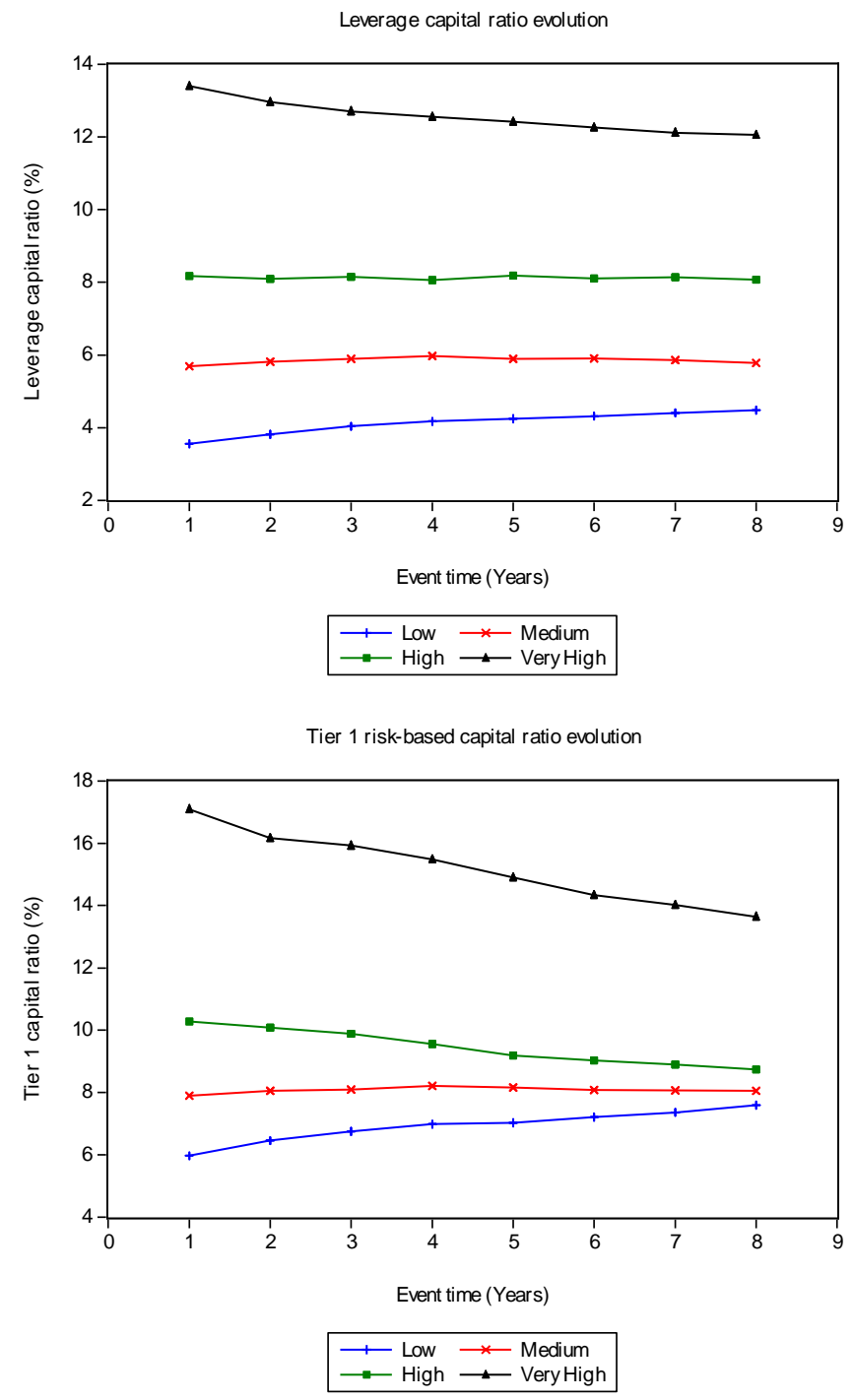

Total risk-based capital ratio evolution

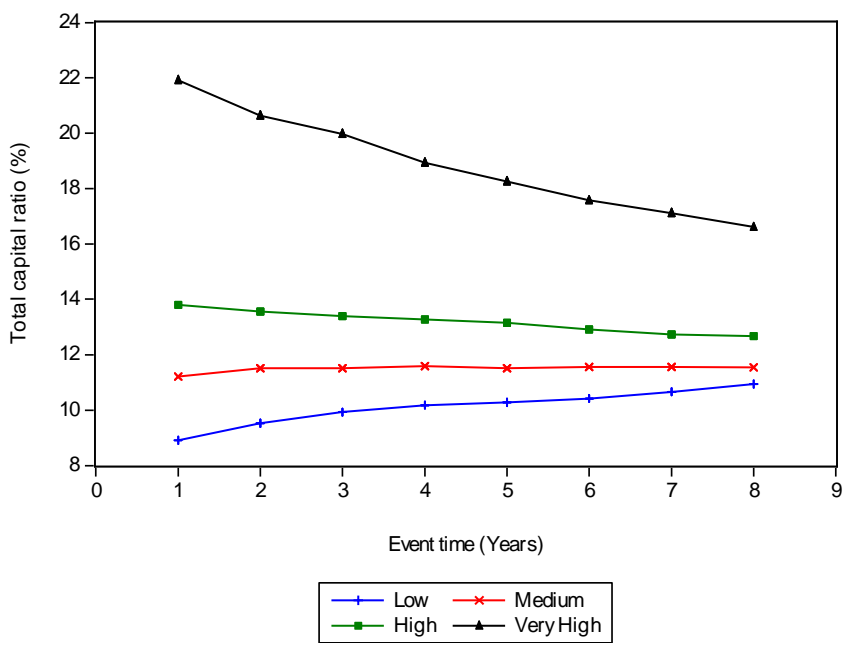


Table 1: Number of banks used to compute the leverage ratio evolution for the bank grouping "Low".

\begin{tabular}{|c|c|c|c|c|c|c|c|c|}
\hline $\begin{array}{l}\text { Event time (years) } \\
\text { Port. form. year }\end{array}$ & 1 & 2 & 3 & 4 & 5 & 6 & 7 & 8 \\
\hline 1992 & 39 & 39 & 38 & 38 & 37 & 36 & 27 & 24 \\
\hline 1993 & 57 & 53 & 52 & 51 & 48 & 36 & 31 & 28 \\
\hline 1994 & 66 & 60 & 58 & 53 & 42 & 34 & 32 & 26 \\
\hline 1995 & 75 & 72 & 67 & 53 & 40 & 39 & 34 & 31 \\
\hline 1996 & 79 & 70 & 58 & 41 & 36 & 31 & 27 & 25 \\
\hline 1997 & 81 & 60 & 42 & 36 & 33 & 28 & 26 & 26 \\
\hline 1998 & 80 & 53 & 46 & 39 & 36 & 33 & 32 & 33 \\
\hline 1999 & 87 & 71 & 65 & 58 & 54 & 49 & 46 & 46 \\
\hline 2000 & 81 & 73 & 64 & 59 & 55 & 50 & 50 & 0 \\
\hline 2001 & 85 & 72 & 65 & 61 & 55 & 57 & 0 & 0 \\
\hline 2002 & 81 & 74 & 67 & 61 & 60 & 0 & 0 & 0 \\
\hline 2003 & 81 & 73 & 60 & 62 & 0 & 0 & 0 & 0 \\
\hline 2004 & 80 & 65 & 67 & 0 & 0 & 0 & 0 & 0 \\
\hline 2005 & 86 & 79 & 0 & 0 & 0 & 0 & 0 & 0 \\
\hline 2006 & 84 & 0 & 0 & 0 & 0 & 0 & 0 & 0 \\
\hline
\end{tabular}


Table 2: The effect of initial capital, traditional and bank specific variables on future bank capital ratios.

\begin{tabular}{|c|c|c|c|c|c|c|c|c|c|c|c|c|}
\hline \multirow{2}{*}{$\begin{array}{c}\text { Variables } \\
\text { Model }\end{array}$} & \multicolumn{4}{|c|}{ Leverage ratio (I) } & \multicolumn{4}{|c|}{ Tier1 risk-based capital ratio (II) } & \multicolumn{4}{|c|}{ Total risk-based capital ratio (III) } \\
\hline & (1) & (2) & (3) & (4) & (1) & (2) & (3) & (4) & (1) & (2) & (3) & (4) \\
\hline \multicolumn{13}{|c|}{ Initial capital } \\
\hline Initial capital ratio & $\begin{array}{c}0.7343 \\
(69.55)^{\star \star \star}\end{array}$ & $\begin{array}{c}0.4643 \\
(33.69)^{\star \star \star}\end{array}$ & $\begin{array}{c}0.4658 \\
(33.28)^{\star \star \star}\end{array}$ & $\begin{array}{c}0.4697 \\
(33.68)^{\star \star \star}\end{array}$ & $\begin{array}{c}0.5759 \\
(47.09)^{\star \star \star} \\
\text { Tradition }\end{array}$ & $\begin{array}{c}0.5035 \\
(35.77)^{\star \star \star} \\
\text { l variables }\end{array}$ & $\begin{array}{c}0.4673 \\
(33.52)^{\star \star \star}\end{array}$ & $\begin{array}{c}0.4700 \\
(33.65)^{\star \star \star}\end{array}$ & $\begin{array}{c}0.5350 \\
(45.83)^{\star \star \star}\end{array}$ & $\begin{array}{c}0.4637 \\
(35.24)^{\star \star \star}\end{array}$ & $\begin{array}{c}0.4148 \\
(31.02)^{\star \star \star}\end{array}$ & $\begin{array}{c}0.4096 \\
(30.68)^{\star \star \star}\end{array}$ \\
\hline Size & & $\begin{array}{c}-0.3179 \\
(-12.61)^{\star * *}\end{array}$ & $\begin{array}{c}-0.3167 \\
(-1223)^{* * *}\end{array}$ & $\begin{array}{c}-0.3143 \\
(-1125)^{* * *}\end{array}$ & & $\begin{array}{l}-0.1994 \\
(-476)^{* * *}\end{array}$ & $\begin{array}{c}-0.3207 \\
(-786)^{* * *}\end{array}$ & $\begin{array}{c}-0.4228 \\
(-981)^{* * *}\end{array}$ & & -0.1703 & $\begin{array}{l}-0.2890 \\
-739)^{* * *}\end{array}$ & $\begin{array}{c}-0.3804 \\
(-877)^{\star \star \star *}\end{array}$ \\
\hline Profit & & 1.4325 & 1.4796 & 1.4723 & & 0.9115 & 1.1812 & 1.3217 & & 0.5972 & 0.7957 & 0.9206 \\
\hline Equity cost & & $\begin{array}{l}(17.16)^{\star \star \star} \\
-0.1151\end{array}$ & $\begin{array}{l}(17.72)^{\star \star \star} \\
-0.1076\end{array}$ & $\begin{array}{l}(17.34)^{\star \star \star} \\
-0.1051\end{array}$ & & $\begin{array}{l}(6.19)^{\star \star \star *} \\
-0.0542\end{array}$ & $\begin{array}{l}(8.56)^{\star \star \star} \\
-0.0667\end{array}$ & $\begin{array}{l}(9.37)^{\star \star \star} \\
-0.0628\end{array}$ & & $\begin{array}{l}(4.81)^{\star \star \star \star} \\
-0.0684\end{array}$ & $\begin{array}{l}(6.77)^{\star \star \star} \\
-0.0552\end{array}$ & $\begin{array}{l}(7.60)^{\star \star \star *} \\
-0.0521\end{array}$ \\
\hline & & $(-9.55)^{\star \star \star}$ & $(-8.79)^{\star \star *}$ & $(-8.58)^{\star * *}$ & & $(-2.60)^{\star \star \star}$ & $(-3.34)^{\star \star \star}$ & $(-3.16)^{\star \star \star}$ & & $(-3.71)^{\star \star \star}$ & $(-3.11)^{\star \star \star}$ & $(-2.93)^{\star * *}$ \\
\hline Economic cycle & & 0.0687 & 0.0731 & 0.0776 & & 0.1131 & 0.1423 & 0.2082 & & 0.1710 & 0.1799 & 0.2217 \\
\hline & & $(2.10)^{\star \star}$ & $(2.23)^{\star *}$ & $(2.33)^{\star *}$ & & $(2.00)^{\star *}$ & $(2.69)^{\star \star \star}$ & $(3.90)^{\star * *}$ & & $(3.17)^{\star \star \star}$ & $(3.53)^{\star * *}$ & $(4.30)^{\star \star \star}$ \\
\hline Competition & & 0.1452 & 0.1435 & 0.1258 & & 0.0135 & 0.0512 & 0.1086 & & 0.2076 & 0.2164 & 0.2395 \\
\hline \multirow{2}{*}{\multicolumn{13}{|c|}{ Bank specific variables }} \\
\hline & & & & & & & & & & & & \\
\hline Credit risk & & & $\begin{array}{l}0.2138 \\
(1.55)\end{array}$ & $\begin{array}{c}0.2696 \\
(1.95)^{*}\end{array}$ & & & $\begin{array}{c}-0.2531 \\
(-0.90)\end{array}$ & $\begin{array}{c}-0.1061 \\
(-0.37)\end{array}$ & & & $\begin{array}{l}0.0134 \\
(0.06)\end{array}$ & $\begin{array}{l}0.0669 \\
(0.30)\end{array}$ \\
\hline Credit demand & & & -0.0056 & -0.0048 & & & -0.0206 & -0.0198 & & & -0.0188 & -0.0189 \\
\hline Credit activity & & & $\begin{array}{l}(-2.82)^{\star * *} \\
-0.0079\end{array}$ & $\begin{array}{l}(-2.41)^{\star *} \\
-0.0103\end{array}$ & & & $\begin{array}{l}(-6.89)^{\star \star \star} \\
-0.0557\end{array}$ & $\begin{array}{l}(-6.59)^{\star \star \star} \\
-0.0681\end{array}$ & & & $\begin{array}{l}(-6.14)^{\star * \star} \\
-0.0561\end{array}$ & $\begin{array}{l}(-6.16)^{\star \star \star} \\
-0.0620\end{array}$ \\
\hline & & & $(-3.09)^{\star * *}$ & $(-3.79)^{\star \star \star}$ & & & $(-13.43)^{\star * \star}$ & $(-15.15)^{* * *}$ & & & $(-13.83)^{\star \star \star}$ & $(-14.31)^{* * *}$ \\
\hline Market fundings & & & & $\begin{array}{l}0.0026 \\
(0.86)\end{array}$ & & & & $\begin{array}{c}0.0296 \\
(6.46)^{\star * \star}\end{array}$ & & & & $\begin{array}{c}0.0178 \\
(3.78)^{\star \star \star}\end{array}$ \\
\hline Bank deposits & & & & $\begin{array}{l}-0.0132 \\
(-5.21)^{\star * \star}\end{array}$ & & & & 0.0024 & & & & 0.0116 \\
\hline Liability cost & & & & 0.0245 & & & & 0.1338 & & & & 0.1328 \\
\hline Intercept & $\begin{array}{c}2.0743 \\
(21.60)^{\star \star \star}\end{array}$ & $\begin{array}{c}6.6667 \\
(12.19)^{\star \star \star}\end{array}$ & $\begin{array}{c}7.0203 \\
(12.19)^{\star * *}\end{array}$ & $\begin{array}{c}(0.93) \\
7.3203 \\
(12.46)^{\star \star \star}\end{array}$ & $\begin{array}{c}3.8693 \\
(26.52)^{\star \star \star}\end{array}$ & $\begin{array}{c}6.7944 \\
(6.36)^{\star \star \star}\end{array}$ & $\begin{array}{c}12.0917 \\
(11.37)^{\star \star \star}\end{array}$ & $\begin{array}{c}(3.23) \\
12.1272 \\
(1127)^{\star * *}\end{array}$ & $\begin{array}{c}5.8022 \\
(33.02)^{\star \star \star}\end{array}$ & $\begin{array}{l}5.5987 \\
(6.04)^{* * *}\end{array}$ & $\begin{array}{c}11.2317 \\
(11.67)^{\star * \star}\end{array}$ & $\begin{array}{c}(3.22) \\
11.3107\end{array}$ \\
\hline & & & & & & & & & & 2741 & 2741 & 2741 \\
\hline$R^{2}$ & 0.6454 & 0.7412 & 0.7420 & 0.7456 & 0.5300 & 0.5582 & 0.6178 & 0.6222 & 0.4435 & 0.4718 & 0.5285 & 0.5343 \\
\hline$\%$ increase in $\mathrm{R}^{2}$ & & $14.84 \%$ & $0.11 \%$ & $0.49 \%$ & & $5.32 \%$ & $10.68 \%$ & $0.71 \%$ & & $6.38 \%$ & $12.02 \%$ & $1.10 \%$ \\
\hline
\end{tabular}

All variables are described in Appendix C. ${ }^{*},{ }^{\star \star},{ }^{\star \star *}$ mean significant at the 10,5 and 1\% level respectively and t-statistics are between parentheses. Column (1) of any of the three dependent variables: Leverage capital ratio (I), Tier1 risk-based capital ratio (II) and the Total risk-based capital ratio (III) presents the results with only one regressor called the initial capital ratio. Column (2) gives the results with five more variables called traditional variables. The subsequent columns (3) and (4) correspond to the inclusion of the bank specific variables added in two different waves starting by asset structure variables followed by market discipline variables. 
Table 3: Speed of adjustment: comparative convergence between risk and non-risk adjusted bank capital ratios.

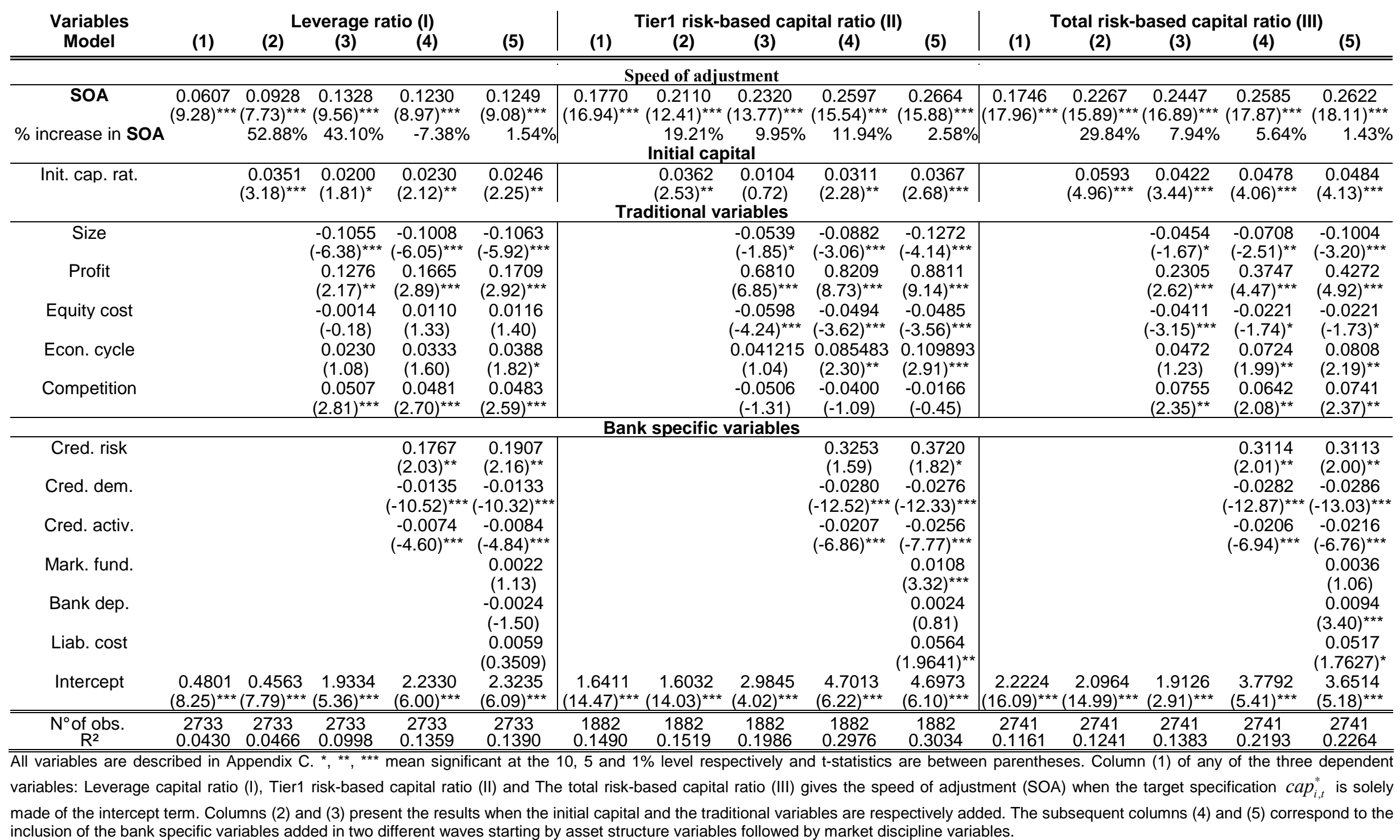


Table 4: Without both time and country fixed effects

\begin{tabular}{|c|c|c|c|c|c|c|c|c|c|c|c|c|c|c|c|c|c|c|}
\hline \multirow{2}{*}{$\begin{array}{c}\text { Variables } \\
\text { Model }\end{array}$} & \multicolumn{4}{|c|}{ Leverage ratio (I) } & \multicolumn{4}{|c|}{ Total risk-based capital ratio (II) } & \multicolumn{5}{|c|}{$\Delta$ Leverage ratio (III) } & \multicolumn{5}{|c|}{$\Delta$ Total risk-based capital ratio (IV) } \\
\hline & (1) & & & (4) & (1) & (2) & (3) & (4) & (1) & (2) & (3) & (4) & (5) & (1) & (2) & (3) & (4) & $(5)$ \\
\hline SOA & & & & & & & & & $\begin{array}{l}0.0622 \\
(9.56)^{\star \star \star}\end{array}$ & $\begin{array}{l}0.0936 \\
(7.80)^{\star * *}\end{array}$ & $\begin{array}{l}0.1342 \\
(9.66)^{\star \star \star}\end{array}$ & $\begin{array}{l}0.1223 \\
(8.93)^{\star \star \star}\end{array}$ & $\begin{array}{l}0.1250 \\
(9.09)^{\star \star \star}\end{array}$ & $\begin{array}{l}0.1730 \\
(17.82)^{\star \star \star}\end{array}$ & $\begin{array}{l}0.2150 \\
(15.22)^{\star \star \star}\end{array}$ & $\begin{array}{l}0.2387 \\
(16.41)^{\star \star \star}\end{array}$ & $\begin{array}{l}0.2563 \\
(17.73)^{\star \star \star}\end{array}$ & $\begin{array}{l}0.2610 \\
(18.05)^{\star \star \star}\end{array}$ \\
\hline In. cap. rat. & $\begin{array}{l}0.7344 \\
(69.55)^{\star \star \star}\end{array}$ & $\begin{array}{l}0.4688 \\
(34.80)^{\star \star \star}\end{array}$ & $\begin{array}{l}0.4738 \\
(34.59)^{\star \star \star}\end{array}$ & $\begin{array}{l}0.4759 \\
(34.69)^{\star \star \star}\end{array}$ & $\begin{array}{l}0.5279 \\
(44.59)^{\star \star \star}\end{array}$ & $\begin{array}{l}0.4520 \\
(34.58)^{\star \star \star}\end{array}$ & $\begin{array}{l}0.4116 \\
(31.13)^{\star \star \star}\end{array}$ & $\begin{array}{l}0.4106 \\
(31.24)^{\star \star \star}\end{array}$ & & $\begin{array}{l}0.0344 \\
(3.11)^{\star * \star}\end{array}$ & $\begin{array}{l}0.0196 \\
(1.78)^{*}\end{array}$ & $\begin{array}{l}0.0258 \\
(2.40)^{\star \star}\end{array}$ & $\begin{array}{l}0.0272 \\
(2.50)^{\star \star}\end{array}$ & & $\begin{array}{l}0.0483 \\
(4.08)^{\star \star \star}\end{array}$ & $\begin{array}{l}0.0339 \\
(2.79)^{\star \star \star}\end{array}$ & $\begin{array}{l}0.0470 \\
(4.04)^{\star \star \star}\end{array}$ & $\begin{array}{l}0.0498 \\
(4.30)^{* \star \star}\end{array}$ \\
\hline Size & & -0.3098 & -0.3055 & -0.3087 & & -0.1812 & -0.2806 & -0.3638 & & & -0.1069 & -0.0942 & -0.1004 & & & -0.0470 & -0.0635 & -0.0901 \\
\hline & & $(-12.42)^{\star \star \star}$ & $(-11.86)^{\star \star \star}$ & $(-11.13)^{\star \star \star}$ & & $(-4.71)^{\star \star \star}$ & $(-7.25)^{\star \star *}$ & $(-8.53)^{\star \star \star}$ & & & $(-6.53)^{\star \star \star}$ & $(-5.68)^{\star \star \star}$ & $(-5.61)^{\star \star \star}$ & & & & & 2) $)^{\star \star \star}$ \\
\hline Profit & & $\begin{array}{l}1.4324 \\
(17.11)^{\star * *}\end{array}$ & $\begin{array}{l}1.4685 \\
(17.46)^{* * *}\end{array}$ & $\begin{array}{l}1.4531 \\
(17.01)^{* * *}\end{array}$ & & $\begin{array}{l}0.5089 \\
(4.10)^{\star * *}\end{array}$ & $\begin{array}{l}0.7809 \\
(6.63)^{* * *}\end{array}$ & $\begin{array}{l}0.9260 \\
(7.56)^{* * *}\end{array}$ & & & $\begin{array}{l}0.1159 \\
(1.96)^{*}\end{array}$ & $\begin{array}{l}0.1539 \\
(2.65)^{* * *}\end{array}$ & $\begin{array}{l}0.1556 \\
(2.64)^{* * *}\end{array}$ & & & $\begin{array}{l}0.1766 \\
(2.01)^{\star *}\end{array}$ & $\begin{array}{l}0.3690 \\
(4.39)^{* * *}\end{array}$ & $\begin{array}{l}0.4247 \\
(4.84)^{* * *}\end{array}$ \\
\hline Equity cost & & $\begin{array}{l}-0.1118 \\
(-9.44)^{\star \star \star}\end{array}$ & $\begin{array}{l}-0.1042 \\
(-8.51)^{\star \star \star}\end{array}$ & $\begin{array}{l}-0.1019 \\
(-8.30)^{\star \star \star}\end{array}$ & & $\begin{array}{l}-0.0831 \\
(-4.52)^{\star \star \star}\end{array}$ & $\begin{array}{l}-0.0584 \\
(-3.27)^{\star \star \star}\end{array}$ & $\begin{array}{l}-0.0531 \\
(-2.96)^{\star * \star}\end{array}$ & & & $\begin{array}{l}-0.0036 \\
(-0.44)\end{array}$ & $\begin{array}{l}0.0114 \\
(1.39)\end{array}$ & $\begin{array}{l}0.0119 \\
(1.43)\end{array}$ & & & $\begin{array}{l}-0.0479 \\
(-3.68)^{\star \star \star}\end{array}$ & $\begin{array}{l}-0.0225 \\
(-1.76)^{*}\end{array}$ & $\begin{array}{l}-0.0217 \\
(-1.69)^{\star}\end{array}$ \\
\hline Econ. cycle & & $\begin{array}{l}0.0514 \\
(1.99)^{\star *}\end{array}$ & $\begin{array}{l}0.0558 \\
(2.15)^{\star \star}\end{array}$ & $\begin{array}{l}0.0625 \\
(2.37)^{* *}\end{array}$ & & $\begin{array}{l}0.1780 \\
(4.13)^{\star * *}\end{array}$ & $\begin{array}{l}0.1678 \\
(4.11)^{* * *}\end{array}$ & $\begin{array}{l}0.1732 \\
(4.23)^{* * *}\end{array}$ & & & $\begin{array}{l}0.0111 \\
(0.66)\end{array}$ & $\begin{array}{l}0.0238 \\
(1.44)\end{array}$ & $\begin{array}{l}0.0281 \\
(1.67)^{*}\end{array}$ & & & $\begin{array}{l}0.0336 \\
(1.10)\end{array}$ & $\begin{array}{l}0.0618 \\
(2.12)^{* *}\end{array}$ & $\begin{array}{l}0.0596 \\
(2.03)^{* *}\end{array}$ \\
\hline Competition & & $\begin{array}{l}0.1604 \\
(5.85)^{\star * *}\end{array}$ & $\begin{array}{l}0.1677 \\
(6.11)^{\star * *}\end{array}$ & $\begin{array}{l}0.1446 \\
(5.00)^{* * *}\end{array}$ & & $\begin{array}{l}0.2663 \\
(6.24)^{\star * *}\end{array}$ & $\begin{array}{l}0.2300 \\
(5.64)^{* * *}\end{array}$ & $\begin{array}{l}0.2355 \\
(5.64)^{\star \star \star}\end{array}$ & & & $\begin{array}{l}0.0448 \\
(2.50)^{* *}\end{array}$ & $\begin{array}{l}0.0532 \\
(3.04)^{\star \star *}\end{array}$ & $\begin{array}{l}0.0498 \\
(2.69)^{* * \star}\end{array}$ & & & $\begin{array}{l}0.0921 \\
(3.03)^{\star * *}\end{array}$ & $\begin{array}{l}0.0626 \\
(2.13)^{* *}\end{array}$ & $\begin{array}{l}0.0657 \\
(2.18)^{\star *}\end{array}$ \\
\hline Cred. risk & & & $\begin{array}{l}0.1187 \\
(0.94)\end{array}$ & $\begin{array}{l}0.1804 \\
(1.41)\end{array}$ & & & $\begin{array}{l}0.2153 \\
(1.05)\end{array}$ & $\begin{array}{l}0.1666 \\
(0.81)\end{array}$ & & & & $\begin{array}{l}0.1606 \\
(2.00)^{\star *}\end{array}$ & $\begin{array}{l}0.1792 \\
(2.20)^{\star *}\end{array}$ & & & & $\begin{array}{l}0.3951 \\
(2.72)^{\star \star \star}\end{array}$ & $\begin{array}{l}0.3541 \\
(2.42)^{\star *}\end{array}$ \\
\hline Cred. dem. & & & $\begin{array}{l}-0.0057 \\
(-2.84)^{\star \star \star}\end{array}$ & $\begin{array}{l}-0.0049 \\
(-2.48)^{\star \star}\end{array}$ & & & $\begin{array}{l}-0.0195 \\
(-6.37)^{\star \star \star}\end{array}$ & $\begin{array}{l}-0.0193 \\
(-6.35)^{\star * *}\end{array}$ & & & & $\begin{array}{l}-0.0135 \\
(-10.6)^{* * *}\end{array}$ & $\begin{array}{l}-0.0133 \\
(-10.4)^{\star \star \star}\end{array}$ & & & & $\begin{array}{l}-0.0285 \\
(-13.1)^{\star * *}\end{array}$ & $\begin{array}{l}-0.0288 \\
(-13.2)^{\star \star \star}\end{array}$ \\
\hline Cred. act. & & & $\begin{array}{l}-0.0060 \\
(-2.47)^{\star *}\end{array}$ & $\begin{array}{l}-0.0086 \\
(-3.27)^{\star \star \star}\end{array}$ & & & $\begin{array}{l}-0.0590 \\
(-15.14)^{\star \star *}\end{array}$ & $\begin{array}{l}-0.0624 \\
(-14.97)^{\star \star \star}\end{array}$ & & & & $\begin{array}{l}-0.0068 \\
(-4.40)^{\star \star *}\end{array}$ & $\begin{array}{l}-0.0078 \\
(-4.63)^{\star \star \star}\end{array}$ & & & & $\begin{array}{l}-0.0211 \\
(-7.38)^{\star \star *}\end{array}$ & $\begin{array}{l}-0.0210 \\
(-6.84)^{\star \star *}\end{array}$ \\
\hline Mark. fund. & & & & $\begin{array}{l}0.0036 \\
(1.19)\end{array}$ & & & & $\begin{array}{l}0.0167 \\
(3.58)^{\star \star \star}\end{array}$ & & & & & $\begin{array}{l}0.0022 \\
(1.13)\end{array}$ & & & & & $\begin{array}{l}0.0033 \\
(0.99)\end{array}$ \\
\hline Bank dep. & & & & $\begin{array}{l}-0.0122 \\
(-4.88)^{\star \star \star}\end{array}$ & & & & $\begin{array}{l}0.0108 \\
(2.80)^{\star \star \star}\end{array}$ & & & & & $\begin{array}{l}-0.0024 \\
(-1.52)\end{array}$ & & & & & $\begin{array}{l}0.0091 \\
(3.32)^{\star \star \star}\end{array}$ \\
\hline Liab. cost & & & & $\begin{array}{l}-0.0070 \\
(-0.30)\end{array}$ & & & & $\begin{array}{l}0.1431 \\
(4.00)^{\star \star \star}\end{array}$ & & & & & $\begin{array}{l}-0.0056 \\
(-0.38)\end{array}$ & & & & & $\begin{array}{l}0.0468 \\
(1.83)^{*}\end{array}$ \\
\hline Intercept & $\begin{array}{l}2.0744 \\
(21.60)^{\star \star \star}\end{array}$ & $\begin{array}{l}6.4210 \\
(11.96)^{\star \star \star}\end{array}$ & $\begin{array}{l}6.5737 \\
(11.55)^{\star \star \star} \\
\end{array}$ & $\begin{array}{l}7.1003 \\
(12.05)^{\star \star \star} \\
\end{array}$ & $\begin{array}{l}5.9012 \\
(33.09)^{\star \star *}\end{array}$ & $\begin{array}{l}5.1319 \\
(5.59)^{\star * \star}\end{array}$ & $\begin{array}{l}11.0606 \\
(11.55)^{\star \star \star}\end{array}$ & $\begin{array}{l}11.1912 \\
(11.68)^{\star \star \star}\end{array}$ & $\begin{array}{l}0.4917 \\
(8.48)^{* * *} \\
\end{array}$ & $\begin{array}{l}0.4690 \\
(8.04)^{\star * \star}\end{array}$ & $\begin{array}{l}2.0542 \\
(5.81)^{\star * \star}\end{array}$ & $\begin{array}{l}2.0668 \\
(5.63)^{\star \star \star}\end{array}$ & $\begin{array}{l}2.2528 \\
(5.88)^{\star \star \star} \\
\end{array}$ & $\begin{array}{l}2.2017 \\
(15.95)^{\star \star \star}\end{array}$ & $\begin{array}{l}2.0930 \\
(14.93)^{\star \star \star}\end{array}$ & $\begin{array}{l}1.8052 \\
(2.79)^{\star \star \star}\end{array}$ & $\begin{array}{l}3.6951 \\
(5.33)^{\star \star \star}\end{array}$ & $\begin{array}{l}3.6132 \\
(5.19)^{\star \star \star}\end{array}$ \\
\hline $\begin{array}{c}\mathrm{N}^{\circ} \text { of obs. } \\
\mathrm{R}^{2}\end{array}$ & $\begin{array}{l}2733 \\
0.6454\end{array}$ & $\begin{array}{l}2733 \\
0.7397\end{array}$ & $\begin{array}{l}2733 \\
0.7402\end{array}$ & $\begin{array}{l}2733 \\
0.7438\end{array}$ & $\begin{array}{l}2741 \\
0.4206\end{array}$ & $\begin{array}{l}2741 \\
0.4602\end{array}$ & $\begin{array}{l}2741 \\
0.5243\end{array}$ & $\begin{array}{l}2741 \\
0.5316\end{array}$ & $\begin{array}{l}2733 \\
0.0324\end{array}$ & $\begin{array}{l}2733 \\
0.0359\end{array}$ & $\begin{array}{l}2733 \\
0.0881\end{array}$ & $\begin{array}{l}2733 \\
0.1266\end{array}$ & $\begin{array}{l}2733 \\
0.1280\end{array}$ & $\begin{array}{l}2741 \\
0.1040\end{array}$ & $\begin{array}{l}2741 \\
0.1094\end{array}$ & $\begin{array}{l}2741 \\
0.1240\end{array}$ & $\begin{array}{l}2741 \\
0.2142\end{array}$ & $\begin{array}{l}2741 \\
0.2224\end{array}$ \\
\hline $\begin{array}{l}\% \text { inc R } \\
\% \text { inc SOA }\end{array}$ & & $12.75 \%$ & $0.07 \%$ & $0.48 \%$ & & $8.60 \%$ & $12.23 \%$ & $1.37 \%$ & & $50,48 \%$ & $43,38 \%$ & $-8,87 \%$ & $2,21 \%$ & & $24,28 \%$ & $11,02 \%$ & $7,37 \%$ & $1,83 \%$ \\
\hline
\end{tabular}

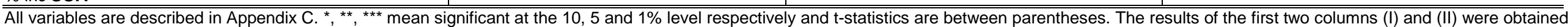

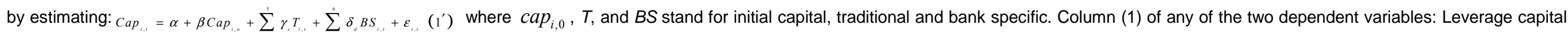

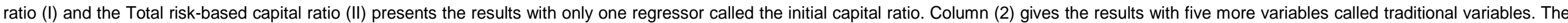

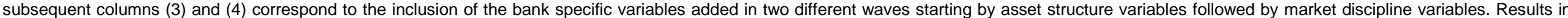

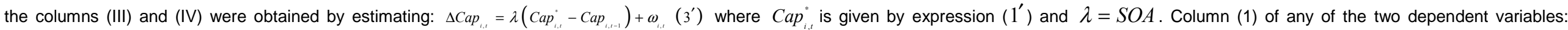

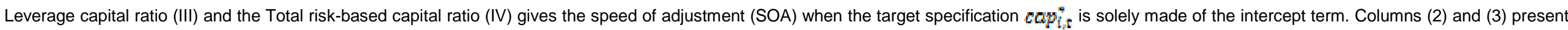

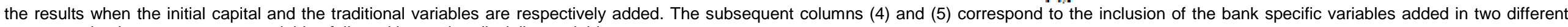
waves starting by asset structure variables followed by market discipline variables. 
Table 5: With both time and country fixed effects

\begin{tabular}{|c|c|c|c|c|c|c|c|c|c|c|c|c|c|c|c|c|c|c|}
\hline \multirow{2}{*}{$\begin{array}{l}\text { Variables } \\
\text { Model }\end{array}$} & \multicolumn{4}{|c|}{ Leverage ratio (I) } & \multicolumn{4}{|c|}{ Total risk-based capital ratio (II) } & \multicolumn{5}{|c|}{$\Delta$ Leverage ratio (III) } & \multicolumn{5}{|c|}{$\Delta$ Total risk-based capital ratio (IV) } \\
\hline & (1) & & & (4) & & (2) & (3) & (4) & $(1)$ & $(2)$ & & (4) & (5) & $(1)$ & & & (4) & $(5)$ \\
\hline SOA & & & & & & & & & $\begin{array}{c}0.0761 \\
(10.41)^{\star * \star}\end{array}$ & $\begin{array}{c}0.1148 \\
(9.22)^{* \star *}\end{array}$ & $\begin{array}{c}0.1384 \\
(9.84)^{\star \star \star}\end{array}$ & $\begin{array}{c}0.1302 \\
(9.43)^{\star * \star}\end{array}$ & $\begin{array}{c}0.1312 \\
(9.47)^{\star * \star}\end{array}$ & $\begin{array}{c}0.1831 \\
(18.14)^{\star \star *}\end{array}$ & $\begin{array}{c}0.2343 \\
(16.27)^{\star \star *}\end{array}$ & $\begin{array}{c}0.2545 \\
(17.33)^{\star \star *}\end{array}$ & $\begin{array}{c}0.2713 \\
(18.42)^{\star \star *}\end{array}$ & $\begin{array}{c}0.2738 \\
(18.65)^{\star \star \star}\end{array}$ \\
\hline In. cap. rat. & $\begin{array}{c}0.6904 \\
(62.51)^{\star \star \star}\end{array}$ & $\begin{array}{c}0.4724 \\
(32.98)^{\star \star \star}\end{array}$ & $\begin{array}{c}0.4756 \\
(32.85)^{\star \star \star}\end{array}$ & $\begin{array}{c}0.4785 \\
(33.10)^{\star \star \star}\end{array}$ & $\begin{array}{c}0.5305 \\
(43.51)^{\star \star \star}\end{array}$ & $\begin{array}{c}0.4594 \\
(33.69)^{\star \star \star}\end{array}$ & $\begin{array}{c}0.4089 \\
(29.97)^{\star \star \star}\end{array}$ & $\begin{array}{c}0.4042 \\
(29.59)^{\star \star \star}\end{array}$ & & $\begin{array}{c}0.0428 \\
(3.82)^{\star * \star}\end{array}$ & $\begin{array}{c}0.0257 \\
(2.26)^{\star \star}\end{array}$ & $\begin{array}{c}0.0299 \\
(2.68)^{\star * \star}\end{array}$ & $\begin{array}{c}0.0306 \\
(2.73)^{\star * *}\end{array}$ & & $\begin{array}{c}0.0606 \\
(4.92)^{\star * *}\end{array}$ & $\begin{array}{c}0.0421 \\
(3.32)^{\star * \star}\end{array}$ & $\begin{array}{c}0.0455 \\
(3.74)^{\star * \star}\end{array}$ & $\begin{array}{c}0.0460 \\
(3.79)^{\star * \star}\end{array}$ \\
\hline Size & & $\begin{array}{c}-0.2866 \\
(-10.57)^{\star * *}\end{array}$ & $\begin{array}{c}-0.2826 \\
(-10.23)^{\star * *}\end{array}$ & $\begin{array}{l}-0.2842 \\
(-9.36)^{\star \star *}\end{array}$ & & $\begin{array}{c}-0.2811 \\
(-6.54)^{\star \star *}\end{array}$ & $\begin{array}{l}-0.3676 \\
(-8.64)^{\star \star * *}\end{array}$ & $\begin{array}{c}-0.4316 \\
(-9.16)^{\star \star *}\end{array}$ & & & $\begin{array}{l}-0.0996 \\
(-5.59)^{\star \star *}\end{array}$ & $\begin{array}{l}-0.0926 \\
(-5.22)^{\star \star *}\end{array}$ & $\begin{array}{c}-0.1001 \\
(-5.14)^{* * \star}\end{array}$ & & & $\begin{array}{l}-0.0974 \\
(-3.15)^{\star * \star}\end{array}$ & $\begin{array}{c}-0.1169 \\
(-3.76)^{* \star *}\end{array}$ & $\begin{array}{c}-0.1340 \\
(-3.88)^{\star \star * *}\end{array}$ \\
\hline Profit & & $\begin{array}{c}1.4615 \\
(16.64)^{\star \star \star}\end{array}$ & $\begin{array}{c}1.5346 \\
(17.22)^{\star \star \star}\end{array}$ & $\begin{array}{c}1.5298 \\
(16.93)^{\star \star \star}\end{array}$ & & $\begin{array}{c}0.6906 \\
(5.12)^{\star * \star}\end{array}$ & $\begin{array}{c}0.9817 \\
(7.67)^{\star \star \star}\end{array}$ & $\begin{array}{c}1.0344 \\
(7.98)^{\star \star \star}\end{array}$ & & & $\begin{array}{r}0.1410 \\
(2.30)^{\star \star}\end{array}$ & $\begin{array}{c}0.2050 \\
(3.37)^{\star \star \star}\end{array}$ & $\begin{array}{c}0.2041 \\
(3.32)^{\star * \star}\end{array}$ & & & $\begin{array}{c}0.2416 \\
(2.49)^{\star *}\end{array}$ & $\begin{array}{c}0.4428 \\
(4.75)^{\star * \star}\end{array}$ & $\begin{array}{c}0.4713 \\
(4.99)^{\star * \star}\end{array}$ \\
\hline Equity cost & & $\begin{array}{c}-0.1170 \\
(-9.50)^{\star \star \star}\end{array}$ & $\begin{array}{c}-0.1093 \\
(-8.76)^{\star \star *}\end{array}$ & $\begin{array}{l}-0.10 \\
-8.64\end{array}$ & & $\begin{array}{l}-0.0718 \\
(-3.80)^{\star \star \star}\end{array}$ & $\begin{array}{l}-0.0 \\
(-3.2\end{array}$ & $\begin{array}{r}-0.0 \\
-2.9\end{array}$ & & & $\begin{array}{c}-0.0025 \\
(-0.29)\end{array}$ & $\begin{array}{l}0.0089 \\
(1.05)\end{array}$ & $\begin{array}{l}0.0094 \\
(1.11)\end{array}$ & & & $\begin{array}{l}-0.0439 \\
(-3.24)^{\star \star \star}\end{array}$ & $\begin{array}{l}-0.0260 \\
(-1.97)^{\star \star}\end{array}$ & $\begin{array}{l}-0.0247 \\
(-1.87)^{*}\end{array}$ \\
\hline Econ. cycle & & $\begin{array}{l}0.0552 \\
(1.29)\end{array}$ & $\begin{array}{l}0.0554 \\
(1.29)\end{array}$ & $\begin{array}{l}0.06 \\
(1.5\end{array}$ & & $\begin{array}{c}0.1870 \\
(2.67)^{\star \star \star}\end{array}$ & $\begin{array}{c}0.1622 \\
(2.44)^{\star *}\end{array}$ & $\begin{array}{c}0.1778 \\
(2.68)^{\star \star \star}\end{array}$ & & & $\begin{array}{l}0.0180 \\
(0.64)\end{array}$ & $\begin{array}{l}0.0203 \\
(0.74)\end{array}$ & $\begin{array}{l}0.0232 \\
(0.85)\end{array}$ & & & $\begin{array}{l}0.0316 \\
(0.63)\end{array}$ & $\begin{array}{l}0.0425 \\
(0.88)\end{array}$ & $\begin{array}{l}0.0448 \\
(0.93)\end{array}$ \\
\hline Competitior & & 0.0555 & $\begin{array}{l}0.0847 \\
(0.88)\end{array}$ & $\begin{array}{l}0.1000 \\
(1.04) \\
\end{array}$ & & $\begin{array}{l}0.1428 \\
(1.31)\end{array}$ & $\begin{array}{l}0.08 \\
(0.8 \\
\end{array}$ & $\begin{array}{l}0.0971 \\
(0.93) \\
\end{array}$ & & & $\begin{array}{l}0.0232 \\
(0.37)\end{array}$ & $\begin{array}{l}0.0355 \\
(0.58) \\
\end{array}$ & $\begin{array}{l}0.0417 \\
(0.68) \\
\end{array}$ & & & $\begin{array}{l}0.0016 \\
(0.02)\end{array}$ & $\begin{array}{r}-0.0651 \\
(-0.86) \\
\end{array}$ & $\begin{array}{c}-0.0582 \\
(-0.77) \\
\end{array}$ \\
\hline Risk & & & $\begin{array}{c}0.2442 \\
(1.69)^{*}\end{array}$ & $\begin{array}{c}0.2960 \\
(2.03)^{\star *}\end{array}$ & & & $\begin{array}{c}0.4284 \\
(1.89)^{\star}\end{array}$ & $\begin{array}{l}0.4227 \\
(1.85)^{\star}\end{array}$ & & & & $\begin{array}{c}0.2028 \\
(2.21)^{\star *}\end{array}$ & $\begin{array}{c}0.2130 \\
(2.29)^{\star *}\end{array}$ & & & & $\begin{array}{c}0.5173 \\
(3.16)^{\star * *}\end{array}$ & $\begin{array}{r}0.4980 \\
(3.01)^{* * *}\end{array}$ \\
\hline Cred. dem. & & & $\begin{array}{c}-0.0068 \\
(-3.38)^{\star * *}\end{array}$ & $\begin{array}{l}-0.0059 \\
(-2.93)^{\star * *}\end{array}$ & & & $\begin{array}{c}-0.0181 \\
(-5.93)^{\star * \star}\end{array}$ & & & & & $\begin{array}{l}-0.0141 \\
(-10.9)^{\star \star *}\end{array}$ & $\begin{array}{c}-0.0139 \\
(-10.7)^{\star \star *}\end{array}$ & & & & $\begin{array}{l}-0.0281 \\
(-12.7)^{* * *}\end{array}$ & $\begin{array}{l}-0.0287 \\
(-12.9)^{\star * *}\end{array}$ \\
\hline Cred. a & & & $\begin{array}{l}-0.0110 \\
(-3.98)^{* * *}\end{array}$ & $\begin{array}{l}-0.0130 \\
(-4.43)^{\star \star *}\end{array}$ & & & $\begin{array}{c}-0.0649 \\
(-14.97)^{\star \star \star}\end{array}$ & $\begin{array}{c}-0.0694 \\
(-15.20)^{\star * *}\end{array}$ & & & & $\begin{array}{l}-0.0092 \\
(-5.22)^{\star * *}\end{array}$ & $\begin{array}{c}-0.0100 \\
(-5.37)^{\star \star \star}\end{array}$ & & & & $\begin{array}{c}-0.0256 \\
(-7.91)^{* * *}\end{array}$ & $\begin{array}{l}-0.0263 \\
(-7.71)^{\star \star \star}\end{array}$ \\
\hline Mark. fund. & & & & $\begin{array}{l}0.0027 \\
(0.80)\end{array}$ & & & & $\begin{array}{c}0.0148 \\
(2.85)^{\star * *}\end{array}$ & & & & & $\begin{array}{l}0.0024 \\
(1.15)\end{array}$ & & & & & $\begin{array}{l}0.0029 \\
(0.77)\end{array}$ \\
\hline Bank dep & & & & $\begin{array}{c}-0.01 \\
(-4.32)^{\star \star *}\end{array}$ & & & & $\begin{array}{c}0.0110 \\
(2.73)^{\star * *}\end{array}$ & & & & & $\begin{array}{l}-0.00 \\
(-1.07)\end{array}$ & & & & & $\begin{array}{c}0.0086 \\
(2.97)^{\star * *}\end{array}$ \\
\hline Liab. cost & & & & $\begin{array}{l}0.0257 \\
(0.94)\end{array}$ & & & & $\begin{array}{c}0.1206 \\
(2.88)^{\star * \star}\end{array}$ & & & & & $\begin{array}{l}0.0024 \\
(0.14)\end{array}$ & & & & & $\begin{array}{l}0.0485 \\
(1.60)\end{array}$ \\
\hline Intercept & $\begin{array}{c}1.9393 \\
(5.70)^{\star \star \star}\end{array}$ & $\begin{array}{c}6.6673 \\
(6.44)^{\star \star \star}\end{array}$ & $\begin{array}{c}7.0455 \\
(6.67)^{\star \star \star}\end{array}$ & $\begin{array}{c}6.9829 \\
(6.54)^{\star \star \star}\end{array}$ & $\begin{array}{c}6.6387 \\
(12.79)^{\star \star \star}\end{array}$ & $\begin{array}{c}8.8857 \\
(4.25)^{\star * \star}\end{array}$ & $\begin{array}{c}16.3176 \\
(8.10)^{\star \star \star}\end{array}$ & $\begin{array}{l}16.3490 \\
(8.11)^{\star * \star}\end{array}$ & $\begin{array}{c}0.4434 \\
(2.19)^{\star *}\end{array}$ & $\begin{array}{c}0.4221 \\
(2.09)^{\star \star}\end{array}$ & $\begin{array}{c}1.9301 \\
(2.82)^{\star * \star}\end{array}$ & $\begin{array}{c}2.3191 \\
(3.40)^{\star \star \star}\end{array}$ & $\begin{array}{c}2.3676 \\
(3.42)^{\star \star \star}\end{array}$ & $\begin{array}{c}2.5058 \\
(6.70)^{\star \star \star}\end{array}$ & $\begin{array}{c}2.4341 \\
(6.53)^{\star \star \star}\end{array}$ & $\begin{array}{c}4.3803 \\
(2.92)^{\star \star \star}\end{array}$ & $\begin{array}{c}7.7732 \\
(5.30)^{\star \star \star}\end{array}$ & $\begin{array}{c}7.5864 \\
(5.17)^{\star \star \star}\end{array}$ \\
\hline $\begin{array}{c}N^{\circ} \text { of obs. } \\
R^{2}\end{array}$ & $\begin{array}{c}2733 \\
0.6777\end{array}$ & $\begin{array}{c}2733 \\
0.7471\end{array}$ & $\begin{array}{c}2733 \\
0.7482\end{array}$ & $\begin{array}{c}2733 \\
0.7502\end{array}$ & $\begin{array}{c}2741 \\
0.4590\end{array}$ & $\begin{array}{c}2741 \\
0.4900\end{array}$ & $\begin{array}{c}2741 \\
0.5457\end{array}$ & $\begin{array}{c}2741 \\
0.5495\end{array}$ & $\begin{array}{c}2733 \\
0.0581\end{array}$ & $\begin{array}{c}2733 \\
0.0632\end{array}$ & $\begin{array}{c}2733 \\
0.1071\end{array}$ & $\begin{array}{c}2733 \\
0.1501\end{array}$ & $\begin{array}{c}2733 \\
0.1509\end{array}$ & $\begin{array}{c}2741 \\
0.1234\end{array}$ & $\begin{array}{c}2741 \\
0.1312\end{array}$ & $\begin{array}{c}2741 \\
0.1456\end{array}$ & $\begin{array}{c}2741 \\
0.2237\end{array}$ & $\begin{array}{c}2741 \\
0.2296\end{array}$ \\
\hline $\begin{array}{c}\% \text { inc } R^{2} / \\
\% \text { inc SOA }\end{array}$ & & $9.29 \%$ & $0.15 \%$ & $0.27 \%$ & & $6.33 \%$ & $10.21 \%$ & $0.69 \%$ & & $50.85 \%$ & $20.56 \%$ & $-5.92 \%$ & $0.77 \%$ & & $27.96 \%$ & $8.62 \%$ & $6.60 \%$ & $0.92 \%$ \\
\hline
\end{tabular}

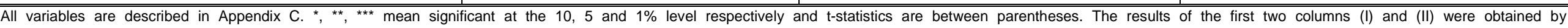

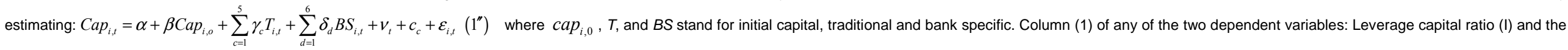

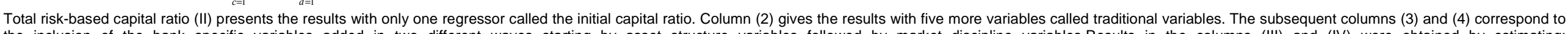

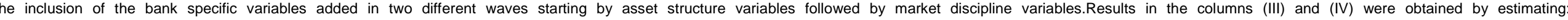

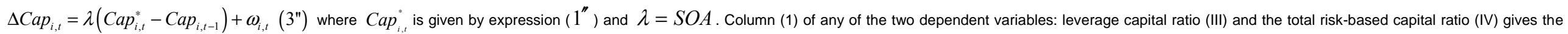

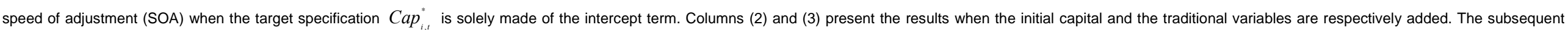
columns (4) and (5) correspond to the inclusion of the bank specific variables added in two different waves starting by asset structure variables followed by market discipline variables. 
Table 6: Alternative econometric method: Panel Least Square with time fixed effects

\begin{tabular}{|c|c|c|c|c|c|c|c|c|c|c|c|c|c|c|c|c|c|c|}
\hline \multirow{2}{*}{$\begin{array}{c}\text { Variables } \\
\text { Model }\end{array}$} & \multicolumn{4}{|c|}{ Leverage ratio (I) } & \multicolumn{4}{|c|}{ Total risk-based capital ratio (II) } & \multicolumn{5}{|c|}{$\Delta$ Leverage ratio (III) } & \multicolumn{5}{|c|}{$\Delta$ Total risk-based capital ratio (IV) } \\
\hline & $(1)$ & $(2)$ & (3) & $(4)$ & $(1)$ & (2) & (3) & (4) & $(1)$ & $(2)$ & (3) & (4) & $(5)$ & $(1)$ & (2) & (3) & $(4)$ & $(5)$ \\
\hline$\overline{\mathrm{SOA}}$ & & & & & & & & & $\begin{array}{l}0.0606 \\
(9.28)^{* * *}\end{array}$ & $\begin{array}{c}0.0927 \\
(7.73)^{\star \star \star}\end{array}$ & $\begin{array}{c}0.1321 \\
(9.83)^{\star \star \star} \\
\end{array}$ & $\begin{array}{c}0.1244 \\
(9.49)^{\star * \star} \\
\end{array}$ & $\begin{array}{c}0.1274 \\
(9.64)^{\star \star \star} \\
\end{array}$ & $\begin{array}{c}0.1745 \\
(17.96)^{* \star \star}\end{array}$ & $\begin{array}{c}0.2266 \\
(15.89)^{\star \star \star}\end{array}$ & $\begin{array}{c}0.2423 \\
(16.78)^{* * *}\end{array}$ & $\begin{array}{c}0.2564 \\
(17.91)^{\star \star \star}\end{array}$ & $\begin{array}{c}0.2596 \\
(18.10)^{\star \star \star}\end{array}$ \\
\hline In. cap. rat. & $\begin{array}{c}0.7343 \\
(69.55)^{* \star *}\end{array}$ & $\begin{array}{c}0.5139 \\
(39.59)^{* \star *}\end{array}$ & $\begin{array}{c}0.5186 \\
(39.88)^{* \star *}\end{array}$ & $\begin{array}{c}0.5227 \\
(40.33)^{* \star \star}\end{array}$ & $\begin{array}{c}0.5350 \\
(45.83)^{\star \star *}\end{array}$ & $\begin{array}{c}0.4709 \\
(36.39)^{* * *}\end{array}$ & $\begin{array}{c}0.4285 \\
(32.82)^{* * *}\end{array}$ & $\begin{array}{c}0.4271 \\
(32.89)^{\star * \star}\end{array}$ & & $\begin{array}{c}0.0351 \\
(3.18)^{\star * \star}\end{array}$ & $\begin{array}{c}0.0229 \\
(2.06)^{* *}\end{array}$ & $\begin{array}{c}0.0275 \\
(2.53)^{* *}\end{array}$ & $\begin{array}{c}0.0299 \\
(2.73)^{* * *}\end{array}$ & & $\begin{array}{c}0.0593 \\
(4.96)^{* * *}\end{array}$ & $\begin{array}{c}0.0443 \\
(3.62)^{\star * *}\end{array}$ & $\begin{array}{c}0.0515 \\
(4.38)^{* * *}\end{array}$ & $\begin{array}{c}0.0531 \\
(4.53)^{\star * *}\end{array}$ \\
\hline Size & & $\begin{array}{c}-0.3490 \\
-13.81)^{* * *}\end{array}$ & $\begin{array}{c}-0.3403 \\
(-13.32)^{* * *}\end{array}$ & $\begin{array}{c}-0.3223 \\
(-11.97)^{\star * *}\end{array}$ & & $\begin{array}{c}-0.2046 \\
(-5.78)^{\star * *}\end{array}$ & $\begin{array}{c}-0.2994 \\
(-8.46)^{* * *}\end{array}$ & $\begin{array}{c}-0.3670 \\
(-9.52)^{\star \star *}\end{array}$ & & & $\begin{array}{c}-0.1066 \\
(-6.54)^{* * *}\end{array}$ & $\begin{array}{c}-0.0974 \\
(-6.04)^{\star * *}\end{array}$ & $\begin{array}{c}-0.0986 \\
(-5.80)^{* \star *}\end{array}$ & & & $\begin{array}{c}-0.0642 \\
(-2.56)^{* *}\end{array}$ & $\begin{array}{c}-0.0819 \\
(-3.20)^{* * *}\end{array}$ & $\begin{array}{c}-0.1037 \\
(-3.72)^{\star \star \star *}\end{array}$ \\
\hline Profit & & $\begin{array}{c}0.9334 \\
(17.10)^{\star * *}\end{array}$ & $\begin{array}{c}0.9753 \\
(17.58)^{* * *}\end{array}$ & $\begin{array}{c}0.9572 \\
(17.30)^{* * *}\end{array}$ & & $\begin{array}{c}0.4188 \\
(5.18)^{\star * *}\end{array}$ & $\begin{array}{c}0.5333 \\
(6.80)^{\star * *}\end{array}$ & $\begin{array}{c}0.5919 \\
(7.52)^{* * *}\end{array}$ & & & $\begin{array}{c}0.0789 \\
(2.15)^{* *}\end{array}$ & $\begin{array}{c}0.1026 \\
(2.80)^{\star * *}\end{array}$ & $\begin{array}{c}0.1038 \\
(2.83)^{* * \star}\end{array}$ & & & $\begin{array}{c}0.1702 \\
(2.97)^{* * *}\end{array}$ & $\begin{array}{c}0.2582 \\
(4.62)^{* * *}\end{array}$ & $\begin{array}{c}0.2826 \\
(5.03)^{\star * *}\end{array}$ \\
\hline Equity cost & & $\begin{array}{c}-0.0693 \\
(-9.70)^{\star * \star}\end{array}$ & $\begin{array}{c}-0.0617 \\
(-8.46)^{\star * \star}\end{array}$ & $\begin{array}{c}-0.0600 \\
(-8.26)^{* * *}\end{array}$ & & $\begin{array}{c}-0.0435 \\
(-4.03)^{* * \star}\end{array}$ & $\begin{array}{c}-0.0335 \\
(-3.16)^{\star \star \star}\end{array}$ & $\begin{array}{c}-0.0326 \\
(-3.08)^{\star \star \star}\end{array}$ & & & $\begin{array}{c}-0.0009 \\
(-0.19)\end{array}$ & $\begin{array}{l}0.0070 \\
(1.52)\end{array}$ & $\begin{array}{l}0.0073 \\
(1.59)\end{array}$ & & & $\begin{array}{c}-0.0253 \\
(-3.32)^{\star * *}\end{array}$ & $\begin{array}{c}-0.0132 \\
(-1.76)^{*}\end{array}$ & $\begin{array}{l}-0.0140 \\
(-1.86)^{\star}\end{array}$ \\
\hline Econ. cycle & & $\begin{array}{c}0.0615 \\
(1.85)^{*}\end{array}$ & $\begin{array}{l}0.0624 \\
(1.87)^{*}\end{array}$ & $\begin{array}{l}0.0546 \\
(1.60)\end{array}$ & & $\begin{array}{c}0.1489 \\
(2.79)^{* * *}\end{array}$ & $\begin{array}{c}0.1602 \\
(3.15)^{\star * \star}\end{array}$ & $\begin{array}{c}0.1915 \\
(3.70)^{\star * *}\end{array}$ & & & $\begin{array}{l}0.0231 \\
(1.11)\end{array}$ & $\begin{array}{l}0.0319 \\
(1.56)\end{array}$ & $\begin{array}{l}0.0340 \\
(1.61)\end{array}$ & & & $\begin{array}{l}0.0347 \\
(0.92)\end{array}$ & $\begin{array}{l}0.0582 \\
(1.61)\end{array}$ & $\begin{array}{l}0.0628 \\
(1.70)^{*}\end{array}$ \\
\hline Competition & & $\begin{array}{c}0.1523 \\
(6.04)^{\star * *}\end{array}$ & $\begin{array}{c}0.1480 \\
(5.86)^{* * \star} \\
\end{array}$ & $\begin{array}{c}0.1191 \\
(4.57)^{\star \star \star} \\
\end{array}$ & & $\begin{array}{c}0.1696 \\
(4.54)^{* * \star}\end{array}$ & $\begin{array}{c}0.1804 \\
(5.07)^{\star * *}\end{array}$ & $\begin{array}{c}0.1991 \\
(5.57)^{\star \star \star}\end{array}$ & & & $\begin{array}{c}0.0468 \\
(2.94)^{\star * \star}\end{array}$ & $\begin{array}{c}0.0443 \\
(2.84)^{* * *}\end{array}$ & $\begin{array}{c}0.0418 \\
(2.59)^{* *}\end{array}$ & & & $\begin{array}{l}0.0602 \\
(2.28)^{* \star}\end{array}$ & $\begin{array}{c}0.0537 \\
(2.12)^{\star \star}\end{array}$ & $\begin{array}{c}0.0611 \\
(2.39)^{\star *}\end{array}$ \\
\hline Risk & & & $\begin{array}{c}0.2419 \\
(2.76)^{\star \star \star}\end{array}$ & $\begin{array}{c}0.2716 \\
(3.11)^{\star * \star}\end{array}$ & & & $\begin{array}{l}0.1420 \\
(1.06)\end{array}$ & $\begin{array}{l}0.1628 \\
(1.22)\end{array}$ & & & & $\begin{array}{c}0.1391 \\
(2.58)^{\star \star \star}\end{array}$ & $\begin{array}{r}0.1469 \\
(2.71)^{\star \star \star}\end{array}$ & & & & $\begin{array}{c}0.2420 \\
(2.56)^{\star *}\end{array}$ & $\begin{array}{c}0.2344 \\
(2.48)^{\star *}\end{array}$ \\
\hline Cred. dem. & & & $\begin{array}{l}-0.0090 \\
(-4.45)^{* * *}\end{array}$ & $\begin{array}{l}-0.0085 \\
(-4.24)^{* * *}\end{array}$ & & & $\begin{array}{c}-0.0253 \\
(-8.42)^{* * *}\end{array}$ & $\begin{array}{c}-0.0258 \\
(-8.62)^{* * *}\end{array}$ & & & & $\begin{array}{l}-0.0141 \\
(-11.3)^{\star * *}\end{array}$ & $\begin{array}{c}-0.0140 \\
(-11.2)^{\star * *}\end{array}$ & & & & $\begin{array}{c}-0.0307 \\
(-14.40)^{* * *}\end{array}$ & $\begin{array}{c}-0.0311 \\
(-14.62)^{* * *}\end{array}$ \\
\hline Cred. act. & & & $\begin{array}{c}-0.0082 \\
(-3.38)^{* \star *}\end{array}$ & $\begin{array}{l}-0.0090 \\
(-3.58)^{* * *}\end{array}$ & & & $\begin{array}{c}-0.0544 \\
(-14.51)^{\star * \star}\end{array}$ & $\begin{array}{c}-0.0581 \\
(-14.86)^{* * *}\end{array}$ & & & & $\begin{array}{c}-0.0068 \\
(-4.54)^{\star * *}\end{array}$ & $\begin{array}{c}-0.0072 \\
(-4.63)^{\star \star \star}\end{array}$ & & & & $\begin{array}{l}-0.0190 \\
(-6.92)^{* * *}\end{array}$ & $\begin{array}{l}-0.0192 \\
(-6.69)^{\star * *}\end{array}$ \\
\hline Mark. fund. & & & & $\begin{array}{c}-0.0014 \\
(-0.48)\end{array}$ & & & & $\begin{array}{c}0.0135 \\
(3.14)^{* * *}\end{array}$ & & & & & $\begin{array}{l}0.0009 \\
(0.53)\end{array}$ & & & & & $\begin{array}{l}0.0020 \\
(0.67)\end{array}$ \\
\hline Bank dep. & & & & $\begin{array}{c}-0.0143 \\
(-6.06)^{* *}\end{array}$ & & & & $\begin{array}{l}0.0120 \\
(3.42)^{* * *}\end{array}$ & & & & & -0.0024 & & & & & 0.0093 \\
\hline Liab. cost & & & & $\begin{array}{c}-0.0010 \\
(-0.04)\end{array}$ & & & & $\begin{array}{c}0.0836 \\
(2.77)^{\star \star \star}\end{array}$ & & & & & $\begin{array}{l}0.0011 \\
(0.08)\end{array}$ & & & & & $\begin{array}{l}0.0307 \\
(1.43)\end{array}$ \\
\hline Intercept & $\begin{array}{c}2.0743 \\
(21.60)^{\star * *} \\
\end{array}$ & $\begin{array}{c}7.0850 \\
(13.21)^{\star * *} \\
\end{array}$ & $\begin{array}{c}7.3640 \\
(13.19)^{\star * *} \\
\end{array}$ & $\begin{array}{c}7.6999 \\
(13.65)^{\star * *} \\
\end{array}$ & $\begin{array}{c}5.8022 \\
(33.02)^{\star * *} \\
\end{array}$ & $\begin{array}{r}6.7446 \\
(8.21)^{\star * *} \\
\end{array}$ & $\begin{array}{c}11.8371 \\
(13.69)^{\star * *} \\
\end{array}$ & $\begin{array}{c}11.7848 \\
(13.60)^{\star * *} \\
\end{array}$ & $\begin{array}{r}0.4800 \\
(8.25)^{\star \star \star} \\
\end{array}$ & $\begin{array}{c}0.4562 \\
(7.79)^{\star * *} \\
\end{array}$ & $\begin{array}{c}1.9941 \\
(5.77)^{\star * \star} \\
\end{array}$ & $\begin{array}{c}2.2247 \\
(6.32)^{* * *} \\
\end{array}$ & $\begin{array}{c}2.3072 \\
(6.43)^{\star * *} \\
\end{array}$ & $\begin{array}{c}2.2224 \\
(16.09)^{\star \star \star} \\
\end{array}$ & $\begin{array}{c}2.0964 \\
(14.99)^{\star \star *} \\
\end{array}$ & $\begin{array}{c}2.4296 \\
(4.15)^{\star * *} \\
\end{array}$ & $\begin{array}{r}4.0967 \\
(6.50)^{\star \star \star} \\
\end{array}$ & $\begin{array}{r}3.9606 \\
(6.25)^{\star \star \star} \\
\end{array}$ \\
\hline $\begin{array}{c}\mathrm{N}^{\circ} \text { of obs. } \\
\mathrm{R}^{2}\end{array}$ & $\begin{array}{c}2733 \\
0.6454\end{array}$ & $\begin{array}{c}2733 \\
0.7171\end{array}$ & $\begin{array}{l}2733 \\
0.7208\end{array}$ & $\begin{array}{c}2733 \\
0.7249\end{array}$ & $\begin{array}{c}2741 \\
0.4435\end{array}$ & $\begin{array}{l}2741 \\
0.4687\end{array}$ & $\begin{array}{c}2741 \\
0.5204\end{array}$ & $\begin{array}{c}2741 \\
0.5264\end{array}$ & $\begin{array}{c}2733 \\
0.0430\end{array}$ & $\begin{array}{c}2733 \\
0.0466\end{array}$ & $\begin{array}{c}2733 \\
0.0701\end{array}$ & $\begin{array}{c}2733 \\
0.1198\end{array}$ & $\begin{array}{c}2733 \\
0.1210\end{array}$ & $\begin{array}{c}2741 \\
0.1161\end{array}$ & $\begin{array}{c}2741 \\
0.1241\end{array}$ & $\begin{array}{c}2741 \\
0.1361\end{array}$ & $\begin{array}{c}2741 \\
0.2125\end{array}$ & $\begin{array}{c}2741 \\
0.2185\end{array}$ \\
\hline $\begin{array}{l}\% \text { inc. R2/ } \\
\% \text { inc. SOA }\end{array}$ & & $10.00 \%$ & $0.51 \%$ & $0.57 \%$ & & $5.38 \%$ & $9.93 \%$ & $1.14 \%$ & & $52.97 \%$ & $42.50 \%$ & $-5.83 \%$ & $2.41 \%$ & & $29.86 \%$ & $6.93 \%$ & $5.82 \%$ & $1.25 \%$ \\
\hline
\end{tabular}

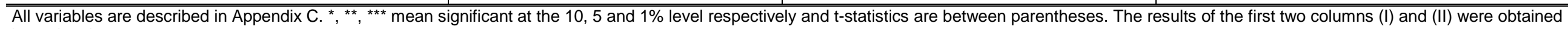
by estimating:

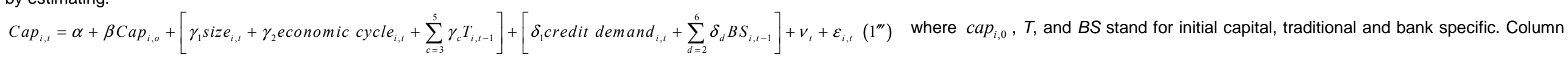

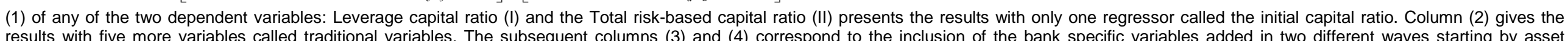

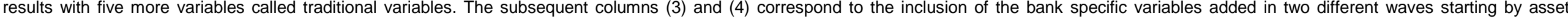

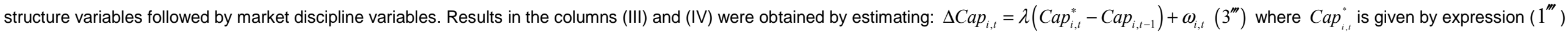

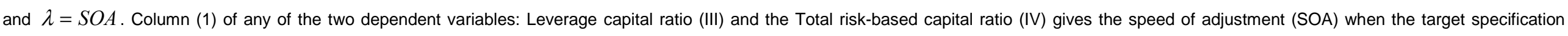

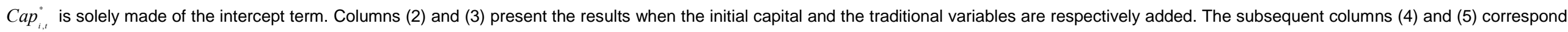
to the inclusion of the bank specific variables added in two different waves starting by asset structure variables followed by market discipline variables. 